\title{
Mucosal Immunology of HIV Infection
}

\author{
Huanbin Xu, Xiaolei Wang, and Ronald S. Veazey \\ Tulane National Primate Research Center, Tulane University School of Medicine, Covington, LA \\ 70433
}

\section{Summary}

Recent advances in the immunology, pathogenesis, and prevention of human immunodeficiency virus (HIV) infection continue to reveal clues to the mechanisms involved in the progressive immunodeficiency attributed to infection but more importantly have shed light on the correlates of immunity to infection and disease progression. HIV selectively infects, eliminates, and/or dysregulates several key cells of the human immune system, thwarting multiple arms of the host immune response, and inflicting severe damage to mucosal barriers, resulting in tissue infiltration of 'symbiotic' intestinal bacteria and viruses that essentially become opportunistic infections promoting systemic immune activation. This leads to activation and recruitment or more target cells for perpetuating HIV infection, resulting in persistent, high level viral replication in lymphoid tissues, rapid evolution of resistant strains, and continued evasion of immune responses. However, vaccine studies and studies of spontaneous controllers are finally providing correlates of immunity from protection and disease progression, including virus-specific $\mathrm{CD} 4^{+} \mathrm{T}$-cell responses, binding antibodies, innate immune responses, and generation of antibodies with potent antibody-dependent cell-mediated cytotoxicity activity. Emerging correlates of immunity indicate that prevention of HIV infection may be possible through effective vaccine strategies that protect and stimulate key regulatory cells and immune responses in susceptible hosts. Further, immune therapies specifically directed towards boosting specific aspects of the immune system may eventually lead to a cure for HIV-infected patients.

\section{Keywords}

HIV; SIV; mucosal immunology; T cell

\section{Introduction}

More than 30 years since the first descriptions of human immunodeficiency virus (HIV) infection in humans, the acquired immunodeficiency syndrome (AIDS) epidemic continues relatively unabated into the $21^{\text {st }}$ century. Although tremendous progress has been made in developed countries where anti-retroviral therapy (ART) is available and prevention of mother to child transmission has become standardized, approximately 50,000 people in the United States are still newly infected with HIV each year (accordning to the Centers for Disease Control) and the epidemic continues to spread in underdeveloped nations. Of those living with HIV, about 70\% live in sub-Saharan Africa, most are unaware of their infection, and many cannot access ART (1). Although HIV no longer means a death sentence for those who can afford treatment, we have made little headway in producing a highly effective

Correspondenc to: Ronald S. Veazey, Tulane National Primate Research Center, Tulane University School of Medicine, 18703 Three Rivers Road, Covington, LA 70433, Tel.: +1 985871 6228, Fax: +1 985871 6510, rveazey@ tulane.edu.

The authors have no conflicts of interest to declare. 
vaccine, and we are no closer to a cure. Education, counseling, and promoting condom use currently remain our best weapons against HIV infection.

We have made great strides towards understanding the pathogenesis and immunology of HIV infection, however, and recent prevention trials in humans and emerging studies in nonhuman primate models of HIV infection suggest effective vaccine and preventions methods are possible. Male circumcision and pre-exposure prophylaxis have shown promise in preventing HIV infection in clinical trials (2), and the results of the RV144 phase 3 vaccine trial in Thailand demonstrated $31.2 \%$ efficacy in prevention of infection $(3,4)$. Further, immunology and vaccine studies continue to expand our understanding of the immune deficits and possible correlates of protection from infection, which may lead to more effective prevention strategies in the near future. Understanding the cellular and molecular mechanisms involved in HIV transmission, immunology, and the development of AIDS will be critical for designing new treatment strategies that may eventually lead to a cure for HIV infection.

\section{Mucosal HIV transmission}

The vast majority of HIV infections result from mucosal transmission. Vaginal and rectal transmission account for most adult infections, but pediatric HIV infections are usually the result of oral ingestion of maternal fluids $(5,6)$. Whether pediatric HIV transmission occurs through the tonsils, oral mucosa, or intestinal tract is uncertain, but pediatric macaque studies have demonstrated oral simian immunodeficiency virus (SIV) transmission to infants is more efficient than vaginal or rectal transmission (7). Although oral transmission is considered rare in adults, newborn infants have a neutral gastric $\mathrm{pH}(8)$, and conceivably HIV could enter through the intestinal tract in infants. Nonetheless, studies in macaque and explant models in which virus is atraumatically applied to mucosal tissues indicate SIV is readily transmitted across the intact rectal, vaginal, cervical, oral, and (to a lesser extent) penile mucosal surfaces $(7,9,10)$. Since most studies examining the early events in mucosal transmission involve vaginal inoculation models, we focus on what is known regarding the early immunologic events associated with exposure and infection of the female reproductive tract (FRT). However, many of the early immunologic events occurring in other mucosal sites of transmission are likely similar.

Although frequently referred to as 'vaginal transmission', the actual anatomical sites where initial HIV infection crosses mucosal barriers and establishes infection in the FRT are somewhat debated. The distal or lower FRT (ectocervix and vagina) of women and macaques is protected by numerous layers of stratified squamous epithelium, which until recently was thought to be an impenetrable barrier to viruses and other microbes. In contrast, the endocervix lacks this thick barrier and is lined only by a single layer of cuboidal epithelial cells, which many believe is a more susceptible site for HIV penetration and transmission. However, infection clearly occurs across the vaginal mucosa, as hysterectomized women, women lacking a cervix, and hysterectomized macaques lacking a cervix can be infected with HIV/SIV (reviewed in 11). Further, administering progesterone or progestins (Depo-provera) to macaques markedly increases vaginal transmission rates, most likely due to thinning of the vaginal and ectocervical epithelium $(12,13)$. Similarly, the use of hormonal contraceptives in women has been recently shown to increase vaginal HIV transmission rates by almost twofold (14). Hormone-induced vaginal epithelial thinning, which brings luminal antigens in closer proximity to underlying target cells in the vagina, may partially account for this increased susceptibility to HIV infection. However, hormonal influences associated with menstrual cycles, pregnancy, menopause, etc., may also affect the production of antimicrobials and/or early mucosal inflammatory responses to exposure, which could influence HIV transmission rates (15). 
The endocervix is also a major site of SIV transmission, as studies in vaginally SIVchallenged macaques have demonstrated foci of infected cells in the cervix within a few days of exposure (16). Conceivably, more proximal sites of the FRT tract like the uterus, fallopian tubes, and ovaries may also be susceptible to infection, but it is simply not known whether initial infections are established in the vaginal, cervical, or other tissues in the FRT. Since most transmission studies have focused on cervicovaginal tissues, we focus on what is known regarding the early immunologic events that occur in these sites following HIV/SIV exposure.

Although the vast majority of HIV infections occur from heterosexual intercourse, The FRT is one of the least efficient sites for HIV transmission. Recent estimates suggest that only 1 in 900 heterosexual exposures result in vaginal HIV transmission (17). This number is consistent with early studies of SIV vaginal transmission in macaques demonstrating that 100 to $>1000$ times more virus is required to establish infection after intravaginal inoculation compared with intravenous inoculation (9). However, even when large doses of virus are 'randomly' applied to the vagina of macaques (with no consideration to age or the menstrual cycle), only a fraction of animals become infected. Therefore, large numbers of animals are usually necessary to demonstrate statistical significance in studies examining rates of vaginal transmission or protection, and the low infection rate also complicates investigations into the early events in transmission.

The reasons why vaginal transmission is so inefficient is unclear. The vaginal environment is far from static, and there are numerous continuously changing variables that may be involved. First, vaginal transmission is clearly associated with higher viral loads in semen, so the 'dose' of exposure is clearly important (17). Second, the vaginal environment is defended by a number of innate mucosal barriers and immune mechanisms that likely impart significant protection from infection. For example, the cervicovaginal surface is coated with mucus, which varies in consistency and volume throughout the menstrual cycle. Recent studies have shown cervicovaginal mucus (CVM) impairs the mobility of HIV particles (18). Thus, the consistency, volume, and quality of CVM may play an important role as the first line of defense of the FRT. In addition, in cycling women and nonhuman primates, the vaginal epithelium varies in thickness and cell number throughout the menstrual cycle, which may provide a formidable barrier to transmission, particularly during the follicular or ovulatory stage of the cycle, when the vaginal epithelium is thickest $(19,20)$. Although the number and distribution of immune cells appears constant in the vagina throughout the cycle $(21,22)$, thinning of the epithelium during the luteal phase may result in virions reaching the underlying target cells involved in transmission (see below). In support of this, multiple studies have demonstrated macaques are more susceptible to vaginal transmission during the luteal phase of the menstrual cycle $(23,24)$. Further, years ago, we demonstrated that administering progesterone to macaques resulted in thinning of the vaginal epithelium and a marked increase in vaginal transmission rates to macaques (25). However, it remains unclear whether this is solely attributed to changes in vaginal thickness and integrity, mucus secretion and quality, and/or cyclic changes in the immunologic responses of the FRT in response to hormones. Others have shown the production of antimicrobial substances and immunoglobulin secretion is markedly affected by changes in hormone levels, indicating cyclic changes in the immune response to antigens may be involved in the susceptibility to vaginal HIV transmission $(15,26,27)$. Nonetheless, we have refined the hormone model of vaginal transmission and are currently using Depo-provera-treated macaques for examining cellular and viral events in vaginal transmission, as well as for testing preventatives. Using this model, we and others $(23,25,28-30)$ have shown that macaques can consistently be infected with much smaller doses of virus following atraumatic intravaginal inoculation a few weeks after administration of progestins. Definitively identifying the first cells infected 
after vaginal and rectal transmission would certainly be helpful for designing new HIV vaccine and prevention strategies.

\section{Mucosal target cells involved in early HIV/SIV transmission}

Regardless of the anatomical site of FRT infection, timed inoculation and viral inactivation studies have demonstrated SIV crosses the mucosal barrier and establishes infection within 60 minutes of vaginal inoculation (31). Possible mechanisms for transmission across an intact squamous epithelium of the vagina involve the interaction of virus with dendritic cells (DCs) and/or $\mathrm{CD} 4^{+} \mathrm{CCR}^{+} \mathrm{T}$ cells in the superficial vaginal mucosa. Multiple studies suggest vaginal epithelial DCs termed Langerhans cells (LCs) may rapidly capture and transport virus to underlying susceptible cells in the initial minutes/hours of infection (12, 31,32 ). Langerhans' cells are abundant in the cervix and vaginal epithelium of humans (33-36) and rhesus macaques $(22,32,37)$. Although vaginal LCs do not express CD4 or CCR5 (22), they do express HLA-DR, CD1a (Fig. 1) and a number of mannose dependent C-type lectin receptors (MCLRs) that can function as highly efficient viral attachment factors $(36,38-41)$. Further, these cells have dendritic cytoplasmic processes that extend through the epithelium to the vaginal lumen, where they are involved in sampling lumenal antigens (32). In mice, it has been demonstrated that antigens are readily adsorbed through LCs of the vagina (42). Thus, a plausible mechanism of mucosal HIV-1 infection involves the capture of viral particles on the vaginal lumenal surface by DC processes expressing one or more MCLRs. Once the virus has been captured, the immature DCs then migrate and present the virus to the underlying lamina propria that contains abundant $\mathrm{CD} 4^{+}$and $\mathrm{CCR} 5^{+}$ $\mathrm{T}$ cells, macrophages, and other cells that may support viral amplification. However, we have been unsuccessful in preventing transmission with topical applications of various DC/ $\mathrm{LC}$ receptor blockers (authors' unpublished observations). Whether $\mathrm{CD} 4^{+} \mathrm{T}$ cells are directly infected by HIV or by HIV presented by LCs in the cervicovaginal mucosa is still unclear, since the dynamics of these interactions are difficult to extrapolate from tissue sections representing single 'snap shots' in time. Detection of the first cell(s) infected after vaginal exposure is difficult to detect by current technologies, indirect, yet emerging, and converging evidence suggest $\mathrm{CD} 4^{+} \mathrm{CCR} 5^{+}$memory $\mathrm{T}$ cells may actually be the primary targets for direct infection and viral replication in the earliest stages of infection.

Abundant $\mathrm{CD}^{+}{ }^{+} \mathrm{CR} 5^{+} \mathrm{T}$ cells reside in the normal vaginal mucosa, and these are among the early targets for SIV infection and CD4 ${ }^{+} \mathrm{T}$-cell destruction $(22,43)$. Although these cells are normally found in the deeper layers of the vaginal epithelium $(21,22)$, breaks, inflammation, and/or hormone-induced physiologic epithelial thinning accompanied by infiltrating $\mathrm{T}$ cells may all bring these target cells closer to viruses penetrating the superficial vaginal epithelium. For example, thinning or less mucus production may allow more contact of the epithelial cells with luminal antigens, promoting local lymphokine production and promoting local inflammatory responses. Further, emerging evidence indicates SIV/HIV alone may trigger inflammatory responses facilitating transmission (44).

Essentially all vaginally transmitted HIV strains utilize CD4 and CCR5 as their receptors for attachment and entry into cells (45). We now know initial HIV and SIV infection is usually acquired from a single virus genotype (or infected cell) in the vast majority of cases, and essentially all of early transmitted founder viruses (TFV) utilize CD4 and CCR5 as their primary receptors $(46,47)$. In early SIV infection, $\mathrm{CD} 4^{+} \mathrm{T}$ cells are almost exclusively infected, and viruses produced later in infection show higher affinity for other myeloid cell types $(48,49)$ The established virus probably arises from a single TFV and nidus of infection, as the detection of a single small cluster of 40-50 cells positive for SIV RNA 3 and 4 days post vaginal exposure suggests small infected founder cell populations form at the initial portal of entry (44). 
The upper layers of the vaginal epithelium lack tight junctions and are permeable to largemolecules and viruses (50). Thus, virions can penetrate the upper layers of the vaginal epithelium freely and reach the deeper, parabasal layers of epithelium where $\mathrm{CD} 4^{+} \mathrm{T}$ cells reside, without requiring capture and transport by LCs (Tom Hope, personal communication). Moreover, epithelial cells respond to external antigens by producing an array of innate immune mediators including chemokines and cytokines that trigger cell recruitment and homing of target cells to the initial site of infection. Thus, repeated HIV exposure to the epithelium itself may result in inflammation and recruitment of CD4 ${ }^{+} \mathrm{CCR}^{+}$ $\mathrm{T}$ cells into the more superficial layers of the epithelium, where they can directly contact virus. Emerging evidence from macaque models suggests HIV may even rely on this early innate inflammatory response to the virus itself to facilitate transmission (see below).

In some experimental models, the probability of mucosal infection is directly proportional to the availability of $\mathrm{CD}^{+}{ }^{+} \mathrm{CCR} 5^{+} \mathrm{T}$ cells in mucosal tissues (51). Further, HIV TFVs replicate well in $\mathrm{CD}^{+} \mathrm{T}$-cell cultures but not in monocyte-derived macrophage cultures $(48,52)$.

Moreover, human ex vivo explant models have shown $\mathrm{CD} 4^{+} \mathrm{CCR} 5^{+} \mathrm{T}$ cells are productively infected without requiring LCs (53). Finally, macaque studies have consistently shown that vaginal transmission of CCR5-using (R5) SHIVs can be completely prevented by topical application of substances that block viral attachment/fusion to either the CD4 binding site of HIV gp120 or CCR5 $(13,29,54-59)$. Although this does not explain how HIV crosses epithelial barriers nor does it necessarily prove $\mathrm{CD} 4^{+} \mathrm{CCR} 5^{+} \mathrm{T}$ cells are the first cells infected, it does imply that infection and amplification within $\mathrm{CD} 4^{+} \mathrm{CCR} 5^{+} \mathrm{T}$ cells is critical to successful vaginal SIV/HIV transmission and the establishment of infection.

Although the earliest events in HIV infection are difficult to examine, the results are certainly consistent with the small-founder-population concept and host tropisms observed in the SIV rhesus macaque model (44). Thus, it is currently thought that HIV infection results from a single nidus of infection in the FRT, most likely from infection of $\mathrm{CD} 4^{+} \mathrm{CCR} 5^{+} \mathrm{T}$ cells, which instigates an inflammatory reaction, resulting in recruitment and activation of additional $\mathrm{CD} 4^{+}$target cells to the site and an expanding nidus of infection (44). Expansion of these foci may either be through recruitment of additional target cells or simply growth of the existing foci, but nonetheless, the nidus continues to grow until infected cells exit the mucosa and enter the afferent lymphatics of the draining lymph nodes, where viral infected cells can be detected within $48 \mathrm{~h}$ of vaginal exposure $(16,44)$.

Infections with other sexually transmitted diseases (STDs) can also increase susceptibility to $\mathrm{HIV}$ infection, likely from the inflammation and recruitment of $\mathrm{CD} 4^{+} \mathrm{CCR} 5^{+}$target cells (60-62). For example, marked increases in $\mathrm{CD}^{+}, \mathrm{CXCR} 4^{+}$and $\mathrm{CCR} 5^{+} \mathrm{T}$ cells have been demonstrated in the endocervix of women vaginally infected with Chlamydia when compared to uninfected women (63). Ulcerative STDs, such as syphilis, Herpes simplex type 2 (HSV-2), and chancroid also result in epithelial damage and loss of mucosal integrity Further, inflammatory STDs, such as Neisseria gonorrhea, Chlamydia trachomatis, and Trichomonas vaginalis also result in the recruitment of inflammatory cells, including activated $\mathrm{CD}^{+} \mathrm{T}$ cells (62). These cells, recruited to control vaginal infections, apparently serve as additional 'fuel' for HIV infection and further local replication, which rapidly results in dissemination to draining lymph nodes and the systemic circulation. In other words, emerging evidence indicates mucosal inflammation, driven by infection, trauma, or innate immune responses to HIV exposure alone, results in recruitment of additional $\mathrm{CD} 4^{+} \mathrm{CCR} 5^{+}$target cells that establishes a local, expanding site of infection in mucosal tissues, which eventually reaches the lymphatics and systemic circulation. 


\section{Early vaginal immune responses to SIV}

Although the normal FRT of women and female macaques does not contain organized or 'inductive' lymphoid tissues, there are resident populations of DCs, LCs, T and B cells, and macrophages in the lamina propria of the vagina and cervix that may be involved in the early response to HIV infection. The distribution and phenotype of immune cells and molecules has been characterized in both macaque $(21,22,32,64)$ and human $(64,65)$ vaginal tissues by flow cytometry and immunohistochemistry.

Vaginal and/or cervical epithelial cells may play a key, early role in the early innate immune responses to HIV. Generally the innate immune system provides the first line of host defense against invading mucosal pathogens. Innate immunity is triggered when host pattern recognition receptors (PRRs) on innate cells detect microbe-associated molecular patterns (MAMPs) within microbial molecules, such as lipopolysaccharide (LPS), flagellin, peptidoglycan, or danger-associated molecular patterns (DAMPs) released from damaged endogenous host cells including ATP and host DNA $(66,67)$. The most studied PRRs are the Toll-like receptors (TLRs), which are transmembrane or cytoplasmic proteins that recognize evolutionarily conserved patterns present in microorganisms, including bacteria, fungi, protozoa, and viruses. To date, 10 different TLRs have been identified in humans; TLR1,TLR2, TLR4, TLR5, TLR6, and TLR10 are expressed on the cell surface and mainly recognize hydrophobic molecules unique to microbes, whereas TLR3, TLR7, TLR8, and TLR9 are located in endosomal compartments and are specialized in recognition of microbial nucleic acids (68).

In early microbial exposure, vaginal epithelial cells as well as DCs recognize pathogens via TLRs and respond to this stimulation by producing antimicrobial peptides as well as chemokines to recruit neutrophils to the site of infection. For example, stimulation of TLRs triggers secretion of the chemokine IL-8, which in turn recruits neutrophils to the vaginal mucosal to combat infection $(69,70)$ and production of antimicrobial peptides such as human beta defensin-2 (hBD-2), which can directly inhibit bacteria (71). Further, in response to recognition of infectious pathogens, the vaginal mucosa mobilizes a variety of other defenses. Antimicrobial proteins, including lysozyme, lactoferrin, and small antimicrobial peptides such as human $\beta$-defensins (HBDs) are secreted in response to HIV infection (72). HIV mucosal exposure also results in rapid upregulation of cytokines and chemokines and upregulation of chemokine receptors, which result in activation and recruitment of additional plasmacytoid DCs (pDCs) and T cells. Infiltrating cells have been shown to secrete IFN- $\alpha, \beta$, and the $\mathrm{CCR}^{+}$chemoattractant chemokines MIP-1a, MIP-1 $\beta$, and CCL5 (RANTES), which recruit additional $\mathrm{CD} 4^{+} \mathrm{CCR} 5^{+} \mathrm{T}$ cells to the site, which may also be infected by HIV, expanding the nidus of infected cells $(16,44,73)$.

These early mucosal front-line defenses are designed to prevent bacterial and viral infections of the FRT, by secretion of multiple inhibitory molecules which usually prevent pathogen replication, including SDF-1, MIP-1a/ $\beta$, and RANTES, and the chemokine macrophage inflammatory protein $3 a / C C$ chemokine ligand 20 (CCL20), which is also known to recruit LC precursors $(74,75)$. However, many if not all of these antimicrobial substances, designed to resist a variety of mucosal infections, may create an inflammatory milieu in the vaginal mucosa, which may actually assist HIV in establishing infection. The early innate mucosal inflammatory response generally facilitates transmission of SIV and HIV-1 by compromising the integrity of the mucosal barrier and increasing target cell availability, where they may also create conditions for highly efficient cell-to-cell spread of infection.

Additional evidence that the inflammatory response facilitates HIV transmission comes from experimental prevention trials. Innate immune agonists applied topically facilitated, 
rather than inhibited, SIV vaginal transmission (76). Further, TLR stimulation increases susceptibility of cells to HIV infection (77). Thus, the early cytokine response is dominated by the induction of pro-inflammatory cytokines, which contribute to local recruitment of additional target cells and viral amplification, whereas the induction of cytokines inducing antiviral activity occur too late to prevent virus replication and dissemination.

Early mucosal inflammation is a key and possibly necessary feature for successful vaginal $\mathrm{HIV}$ transmission. Once target cells $\left(\mathrm{CD} 4^{+} \mathrm{CCR} 5^{+} \mathrm{T}\right.$ cells) in the FRT lamina propria are infected with the primary founder viruses, a cytokine/chemokine 'storm' is released consisting mainly of proinflammatory mediators (78), which recruit additional target cells to the site, perpetuating local infection, until viral-infected cells reach draining lymph nodes, and then the gut, which contains the majority of the hosts viral target cells for HIV replication, amplification, and establishment of irreversible infection. Precisely how the virus or viral infected cells travel from the draining lymph nodes to the gut in the earliest days of transmission remain a mystery and a focus of intense investigation in our laboratory, as it may provide keys to the design of an effective vaccine.

\section{The gastrointestinal tract and HIV}

The gastrointestinal tract is arguably the most important organ in the pathogenesis of SIV and HIV infection (79). Regardless of the site of infection, the intestinal mucosa essentially serves as the 'feeding ground' for HIV amplification in early infection. Further, in chronic infection, the gut-associated lymphoid tissues (GALT) are among the largest and most important sites of persistence for virus in SIV-infected macaques (80) and, by inference, HIV-infected patients.

The small intestine is the longest organ in the human body, measuring roughly 16 feet with an approximate diameter of $1 \mathrm{inch}$. Lying just beneath the single layer of intestinal epithelial cells, the lamina propria contains abundant activated $\left(\mathrm{CD} 69^{+}\right)$, memory $\mathrm{CD} 4^{+} \mathrm{T}$ cells engaged in ether promoting [T-helper 17 (Th17) cells] or inhibiting [T-regulatory (Treg) cells] immune responses to foreign and dietary antigens encountered through absorption through the intestinal epithelial cells. Although there is little organized lymphoid tissue in the upper small intestine, the number of $\mathrm{T}$ cells in the epithelium and lamina propria of this 'effector site' alone has been estimated to exceed the number of $\mathrm{T}$ cells in the rest of the body. Thus, the majority of HIV target cells necessary for viral expansion and persistence lie in the intestinal tract, making this tissue a primary focus of immunologic investigations (79, 81). Regardless of the route of transmission, numerous studies in macaques and humans have shown that within days of infection, there is massive infection and depletion of activated, memory, $\mathrm{CD} 4^{+} \mathrm{CCR}^{+} \mathrm{T}$ cells in the intestine of SIV-infected macaques $(82,83)$ and HIV-infected humans (84-86). Early peak viral replication in plasma likely corresponds to this massive infection and amplification in intestinal tissues. Tremendous viral diversification occurs during this burst of replication, and subsequently, multiple escape mutants are generated and selected under the pressure of ensuing adaptive immune responses (87).

Similar to the vaginal mucosa, TLRs are expressed on intestinal epithelial cells, macrophages, dendritic cells, B cells, T cells and stromal cells, and are critical for intestinal homeostasis. Binding of TLRs activates the innate immune response characterized by NF$\mathrm{KB}$ activation, cytokine production, and chemokine-mediated recruitment of acute inflammatory cells. Normally, TLR signaling in the intestine is involved in epithelial cell proliferation, IgA production, maintenance of tight junctions and antimicrobial peptide expression (88-90). Nucleotide-binding oligomerization domain receptors (NOD proteins) are another class of innate receptors that recognize PAMPs. NOD1 is expressed by intestinal 
epithelial cells, and is required for recognition of invasive Gram-negative bacteria (91). Interestingly, the formation of gut-associated lymphoid tissue (GALT) is also induced by the presence of Gram-negative commensal bacteria through NOD1 signaling (92). Thus, the intestinal tract is unique in that it is the only organ in the body that actually requires constant interaction with a complex community of resident microbes to develop and function properly. It is now known that commensal bacteria in the intestine modulate the differentiation and maturation of the mucosal immune system, and are essential for mammalian health. Communication between the microbiota and the host establishes and maintains immune homeostasis, enabling protective immune responses against pathogens while preventing adverse inflammatory responses to harmless commensal microbes. The density of bacteria increases from the proximal small intestine to the colon, and these microbes aid the host by breaking down food into absorbable products, preventing the outgrowth of pathogenic organisms, and shaping the immune compartments, in exchange for an environment with a constant influx of nutrients necessary for their survival $(93,94)$. Thus, the microbial communities that inhabit the mammalian intestine, termed the intestinal microbiota, maintain a symbiotic relationship with their host. However, microbial products breeching the intestinal epithelium and reaching the lamina propria may activate the innate immune response. Innate pattern-recognition receptors such as TLRs, NLRs, and CLRs play a crucial role in the host recognition of probiotics and other microorganisms. Signaling via these receptors directly influences the chemokine and cytokine response of dendritic cells as well as the crosstalk between the epithelium and the immune cells in the lamina propria for orchestrating proper immune responses during host defense, which can influence the population of effector and regulatory T-cell subsets in the mucosa. For example, colonization of the gut with certain bacteria elicits IL-17 and IL-22-producing Th17 cells in the lamina propria $(95,96)$.

Loss of intestinal immune regulation leading to aberrant immune responses to commensal microbiota are believed to precipitate inflammation observed in the gastrointestinal tract of patients with inflammatory bowel diseases (IBD), Crohn's disease and ulcerative colitis (97). Innate immune receptors that recognize conserved components derived from the microbiota are widely expressed by both epithelial cells and leukocytes of the gastrointestinal tract and play a key role in host protection from infectious pathogens. Abnormal innate immune activation may also drive intestinal pathology, as patients with IBD exhibit extensive infiltration of innate immune cells to the inflamed intestine. Thus, a balanced interaction between the microbiota and innate immune activation is required to maintain a healthy mutualistic relationship between the microbiota and the host. Disruption of this fine-tuned regulation results in alterations in intestinal mucosal integrity, which may actually play a causative role in the systemic immune activation typical of SIV/HIV infection.

The intestinal epithelium and immune system interact with dietary antigens and enteric microbiota in a highly regulated manner to maintain mucosal homeostasis, by simultaneously preventing immune responses to dietary antigens, while promoting inflammatory responses to potential pathogens. Several subsets of $\mathrm{T}$ cells in the intestine are involved in this regulation including $\mathrm{CD} 4^{+} \mathrm{T}$-helper 17 cells (Th-17), T-regulatory (Treg)cells, $\gamma \delta \mathrm{T}$ cells, $\mathrm{CD} 8^{+} \mathrm{T}$ cells, natural killer (NK), and NK-T cells. These cells contribute to the mucosal response to pathogens by secreting a variety of key regulatory cytokines including interleukin-17A (IL-17A), IL-17F, IL-22, and IL-26 (98). Importantly, intestinal $\mathrm{CD}^{+} \mathrm{T}$ cells play major regulatory roles in intestinal mucosal homeostasis and defense against microbial invasion. Disruption of this immune homeostasis resulting from HIV infection and massive intestinal CD4 ${ }^{+} \mathrm{T}$-cell loss can thus result in alterations in the immune responses to antigens, as well as changes in the commensal intestinal bacterial microflora. 
In the distal small intestine and throughout the large intestine, inductive immune tissues organized lymphoid tissues including Peyer's patches (terminal ileum) and isolated lymphoid follicles are distributed throughout the lamina propria, and all of these are covered by a specialized follicle-associated epithelium (FAE) containing M cells, which pinocytose and sample antigens in the lumen (99). These inductive lymphoid tissues have a structure resembling lymph nodes, with B-cell follicles surrounded by mantle zones primarily consisting of resting $\mathrm{CD}^{+}$and $\mathrm{CD} 8^{+} \mathrm{T}$ cells (Fig. 2). Antigens encountered through the FAE are presented to $\mathrm{T}$ and $\mathrm{B}$ cells, which recirculate and home preferentially to the diffuse lamina propria of the intestine as activated, effector $\mathrm{T}$ cells or antibody secreting plasma cells. Thus, virtually all of the $\mathrm{CD} 4^{+} \mathrm{T}$ cells in the diffuse lamina propria (an immune effector site) of the intestine are highly activated $\mathrm{CD}^{+} \mathrm{T}$ cells (Fig. 3), most of which express the CCR5 coreceptor, and these are the major targets for early SIV/HIV infection and amplification $(85,86,100,101)$. In fact, early peak viral replication coincides with intestinal infection and viral amplification within these intestinal $\mathrm{CD} 4{ }^{+} \mathrm{CCR} 5^{+} \mathrm{T}$ cells. Although the intestine contains abundant $\mathrm{CD} 4^{+} \mathrm{T}$ cells, recent studies have shown that $\mathrm{CD}^{+} \mathrm{T}$ cells in the intestinal tract are very heterogeneous, having a variety of phenotypes and regulatory functions. Thus, infection and depletion of intestinal $\mathrm{CD} 4^{+} \mathrm{T}$ cells has dire consequences on intestinal integrity and immune functions.

In chronic infection, systemic immune activation is a hallmark of HIV/SIV infection (102), and a better predictor of disease progression than either plasma viral load or peripheral blood CD4 ${ }^{+}$T-cell counts $(103,104)$. Both HIV and SIV infection (in susceptible hosts) results in marked and persistent immune activation, leading to the development of AIDS. However, SIV infection of nonprogressing hosts (that do not develop AIDS) does not result in persistent immune activation. In fact, chronic activation is a crucial factor that distinguishes pathogenic from nonpathogenic SIV infection in non-human primates (105-108). Thus, similar to the immunologic events described above that promote early mucosal infection and transmission, chronic systemic immune activation may be at least be partly responsible for the progressive immunologic decline and the development of AIDS in susceptible hosts.

Systemic activation in SIV/HIV patients is characterized by (i) high - cell turnover and proliferation of T-cell targets supportive of continued viral replication (109-111), (ii) high levels of immune activation and exhaustion of B and T-cell clones (112-114), (iii) increased frequencies of apoptotic $\mathrm{T}$ cells (115), and (iv) increased production of pro-inflammatory and pro-apoptotic cytokines known as the 'cytokine storm' $(78,116,117)$. Increasing evidence suggests much if not most of the systemic activation characteristic of HIV infection may be the result of increased damage of lymphoid and intestinal mucosal tissues leading to microbial translocation $(118,119)$.

\section{Microbial translocation}

Chronic immune activation of HIV/SIV infection may result from intestinal mucosal damage and leakage of bacterial products from the intestinal lumen into the systemic circulation, in a process termed microbial translocation $(118,120,121)$. Pathogenic SIV infection results in disruption of the intestinal barrier in GALT, and the translocation of commensal microbial products from the intestinal lumen into the systemic circulation, resulting in systemic immune activation $(118,122)$. These bacterial and fungal products may include peptidoglycan, lipoteichoic acid, lipopolysaccharide (LPS), flagellin, ribosomal DNA (rDNA) and unmethylated CpG-containing DNA. These products activate a number of immune receptors including nucleotide-binding oligomerization domain 1 (NOD1) and NOD2, as well as Toll-like receptor 2 (TLR2), TLR4, TLR5, TLR6, and TLR9. Innate immune cells such as monocytes, macrophages and dendritic cells, binding of these 
receptors to microbial products, activates a signaling cascade, eliciting the production of pro-inflammatory cytokines including interleukin-1 $\beta$ (IL-1 $\beta$ ), IL-6, tumor necrosis factor (TNF), and type I interferons (IFN- $\alpha$ and IFN- $\beta$ ). Although these responses may be beneficial, if not essential, to the host in response to most infections, pro-inflammatory cytokines can induce tissue damage, increasing the proliferation of local immune cells. This provides SIV/HIV with a continuous supply of activated $\mathrm{CD} 4^{+} \mathrm{T}$ cells to which are continually depleted by viral lysis and extensive apoptosis $(116,123,124)$.

HIV/SIV-induced immunodeficiency is characterized by progressive functional immune impairment, loss of $\mathrm{CD}^{+} \mathrm{T}$ cells, and severe disruption of gut-associated lymphoid tissues, which limits immune reconstitution, even after initiation of anti-retroviral therapy (ART). Twenty percent of HIV-1-infected patients have no significant increase in their peripheral blood $\mathrm{CD} 4^{+} \mathrm{T}$-cell count after initiation of HAART, and few reconstitute $\mathrm{CD} 4^{+} \mathrm{T}$-cell counts to normal levels even after years of ART. Even with partial normalization of peripheral blood $\mathrm{CD} 4^{+} \mathrm{T}$-cell counts, populations of $\mathrm{CD} 4^{+} \mathrm{T}$ cells remain depleted by as much as $50 \%$ in secondary lymph nodes (LNs) and gut associated lymphoid tissue (GALT) $(84,125,126)$, suggesting perpetual damage of lymphoid structures. Intestinal epithelial damage, including loss of intestinal epithelial cells (enterocytes) and disruption of tight junctions between the cells, may lead to increased villous atrophy, malabsorption of nutrients and diarrhea, intestinal barrier permeability, microbial translocation, and changes in the intestinal microflora and virome. Loss of enterocytes may be directly attributed virus production or bystander effects (127). Tight junction loss occurs within 14 days postinfection. Of these, villous atrophy is accompanied with crypt hyperplasia and resulting in reduction of immunoglobulin A (IgA)-producing plasma cells, which is consistent with underlying B cell dysfunction and decreased IgA concentrations in the intestinal lumen in SIV-infected animals and HIV-infected individuals. Intestinal damage precipitated by HIV/ SIV infection leads to microbial translocation, which in turn is associated with systemic immune activation, loss of Th17 cells, and disease progression.

A chief characteristic of the immune system is the ability to rapidly expand rapidly the number of antigen-specific lymphocytes to combat infection; however, HIV preferentially infects and destroys HIV-specific CD4 ${ }^{+} \mathrm{T}$ cells (128), and evidence in NHP models indicates SIV rapidly and selectively infects and kills dividing $\mathrm{CD}^{+} \mathrm{T}$ cells, regardless of their specificity (124), making it difficult to fully quantify the actual dynamics of the cellular immune response to infection (129). However, converging evidence suggests SIV/HIV selectively infects and eliminates specific types of $\mathrm{CD}^{+} \mathrm{T}$ cells, which results in dampening of the immune response to HIV infection, while simultaneously inducing nonspecific immune stimulation through microbial translocation, resulting in a continuous supply of target cells to support viral replication and persistence throughout the life of the host. Moreover, persistent depletion of specific $\mathrm{CD} 4^{+} \mathrm{T}$-cell subsets likely induces marked immunodeficiencies in cellular and humoral responses, and locally, marked alterations in the intestinal flora, as recently indicated by the discovery of marked expansion of the intestinal virome in SIV-infected macaques (130). Thus, previously unsuspected, opportunistic viral infections of intestinal mucosal cells may be contributing to the destruction of intestinal epithelia and loss of barrier function.

\section{Key CD4 ${ }^{+} \mathrm{T}$ cell subsets involved in HIV pathogenesis}

Massive and early depletion of activated, memory $\mathrm{CD}^{+} \mathrm{T}$ cells is a hallmark of HIV/SIV infection $(85,86,100,101,131-133)$. Since most activated memory T cells co-express CCR5 and are transcriptionally active, logically these cells are a target for direct HIV infection and lysis. However, advances in phenotyping and functional analyses have shown that there are several distinct subsets of $\mathrm{CD} 4^{+} \mathrm{T}$ cells that play key roles in immune regulation and 
homeostasis, particularly in mucosal tissues. Although the reasons are not entirely clear, it is increasingly apparent that certain subsets of $\mathrm{CD} 4^{+} \mathrm{T}$ cells are selectively infected and eliminated in HIV infection, whereas others are relatively spared, resulting in marked changes in immune homeostasis, and the inflammatory response to HIV, and other pathogens. Although difficult to examine in humans, correlates between this marked change in immune homeostasis most likely occurs first in the intestinal tract, where it is evident from direct and indirect evidence that loss of regulatory $\mathrm{T}$ cells in the gut results in rapid changes in immune phenotype, function, barrier permeability, and changes in the intestinal flora, which are apparently all regulated by key mucosal $\mathrm{CD} 4^{+} \mathrm{T}$-cell subsets.

\section{The Th1/Th2 paradigm}

Originally, effector $\mathrm{CD}^{+} \mathrm{T}$ cells were defined based on their cytokine secretion patterns, as either pro-inflammatory responses (Th1) producing IFN- $\gamma$, IL-2, lymphotoxin- $a$, and/or TGF- $\beta$ which drive cell mediated immune responses to control intracellular pathogens, or Th2 responses, producing IL-4, IL-5, IL-6, IL-10, and IL13, which dampen cellular responses, and promote humoral responses to control extracellular pathogens (134-136). However, this paradigm is continuously evolving, as overlap exists with some of the functions and cytokines produced by these cells, and as new Th subsets are identified that do not fit into these defined categories (i.e. Th17 cells, innate lymphoid cells, see below). Nonetheless, in early HIV and SIV infection, the cytokine storm described above consists largely of pro-inflammatory cytokine responses, consistent with a Th1 response. Some of these cytokines have antiviral activity, such as IFN $\gamma$, IL-15, and IL-18 which enhance innate and adaptive cellular immune responses (137). However, in the case of HIV infection, the intense early cytokine response may promote viral replication and immunopathology (137). Although there is marked patient variation and some discrepancy in the literature, it appears that as HIV disease progresses, the profile appears to shift from a Th1 to Th2 response, as evidenced by decreased production of IFN- $\gamma$, IL-2, and IL-12, and an increase in production of IL-4, IL-5, IL-6, and IL-10 $(138,139)$, which are associated with more rapid disease progression in HIV patients (140) and SIV-infected macaques $(139,141)$. Excessive activation of $\mathrm{CD}^{+} \mathrm{T}$ cells and preferential replication of HIV-1 in Th1 cells may eventually result in a shift from inflammatory to a suppressive response, which may be associated with the progression to AIDS (142). In support of this, HIV preferentially infects Th1 type cells ex vivo $(142,143)$. However, this Th1/Th2 paradigm is continuously evolving, as several other key regulatory cells have been identified that do not clearly follow this paradigm.

\section{Th17 cells}

Another major $\mathrm{CD}^{+} \mathrm{T}$-cell subset that is targeted and eliminated early in SIV/HIV infection are Th17 cells (121). Th17 cells represent a distinct lineage from Th1 and Th2 cells, and are characterized by the production of IL-17A, IL-17F, IL-22, and IL-26 (144). Th17 cell differentiation is directed by the transcription factor ROR $\gamma \mathrm{t}$, which appears specific for the Th17 lineage. The pro-inflammatory cytokines IL- 6 and TGF- $\beta$ appear to drive Th17 differentiation, at least in the mouse model, while IL-23 appears to be indispensable for the protective effect of the Th17 response against mucosal pathogens like C. rodentium, Klebsiella pneumoniae, and S. typhimurium $(98,144)$.

Th17 cells are important mediators of immune defenses in the gut and are induced by the microbiota in the intestinal lamina propria (145). Th17 cells produce IL-17 and IL-22 in response to stimulation, which promote recruitment of neutrophils to sites of bacterial infection, induce enterocyte proliferation, maintain mucosal epithelial integrity, and induce production of antibacterial defensins, and thus play an important role in antibacterial immunity (121). Th17-dependent innate response mechanisms, including neutrophil activation and epithelial cell antimicrobial peptide secretion, appear essential for proper host 
defense against extracellular and intracellular bacterial pathogens in the gut. Expansion of Th17 cells can also be negatively regulated by intestinal epithelial cells, which produce IL-25 following microbial recognition (146). IL-17A is constitutively expressed in GALT and epithelial cells of the small intestine, where it plays a major role in the defense against intestinal bacterial pathogens (147). In addition, IL-17A regulates the expression of $\beta$ defensin 3 in the intestinal epithelium, which can effectively kill bacteria prior to invasion of the mucosa (148).

In pathogenic SIV and HIV infections, Th17 cells are rapidly depleted in the intestine $(121,149-152)$. Since Th17/IL-17 are clearly involved in maintenance of intestinal integrity and resistance to bacterial invasion of the gut, the selective depletion of Th17, and innate lymphoid cells (ILCs) that also produce IL-17 (153) may play a key role in the loss of intestinal mucosal integrity, resulting in microbial translocation. In contrast, gut resident Th17 cells are preserved in natural hosts of SIV, which may contribute to the lack of microbial translocation and chronic immune activation in SIV-infected, nonprogressing hosts $(121,154)$. Normal levels of Th17 cells have also been reported in HIV infected elite controllers (155) and long-term nonprogressors (156), which is also consistent with a role for these cells in protection against HIV disease progression.

\section{Treg cells}

Treg cells are a subgroup of $\mathrm{T}$ lymphocytes with immunosuppressive activities. Classical Tregs are immunophenotypically defined as $\mathrm{CD} 25^{\mathrm{hi}}, \mathrm{CD} 127^{\mathrm{lo}}$, and they intracellularly express the Forkhead box P3 protein (FoxP3)(157) and are abundant in the intestine (Fig. 4). During progressive HIV-1 infection, the relative frequency of classical Tregs is increased, while their absolute counts are reduced as a consequence of lower total $\mathrm{CD} 4^{+} \mathrm{T}$-cell counts (158). This observation suggests Tregs decline at a slower rate than conventional CD4 ${ }^{+} \mathrm{T}$ cells during in HIV-1 infection, indicating an imbalance of these cells may play an important role in the immune pathogenesis of HIV-1 infection. Increased frequencies of Treg cells have been documented in the GI tract of macaques with progressive pathogenic SIV infection, where their frequency is positively correlated with viral load (159). In HIVinfected humans, Treg cells suppress virus-specific T-cell responses, and it has been proposed that chronic infection leads to induction of Treg responses that suppress the antiviral immune response to HIV, as another means of immune escape (160).

\section{Proliferating $\mathrm{CD}^{+}{ }^{+} \mathrm{T}$ cells}

Evidence indicates recently dividing $\mathrm{CD} 4^{+} \mathrm{T}$ cells are rapidly and selectively eliminated in early SIV infection, indicating SIV targets not only memory $\mathrm{CD}^{+} \mathrm{T}$ cells but also cells proliferating in response to non-specific antigenic stimulation (124). Although selective infection and destruction of HIV-specific $\mathrm{CD}^{+} \mathrm{T}$ cells has been described (128), emerging evidence suggests that most of the proliferating $\mathrm{CD}^{+} \mathrm{T}$ cells are susceptible to destruction, possibly due to their co-expression of CCR5, and state of activation $(124,129)$. Thus, following SIV/HIV infection, proliferative responses to new antigens or pathogens may be thwarted by the selective infection and elimination of the earliest responding $\mathrm{CD} 4^{+} \mathrm{T}$ cells, thus impairing primary responses to invading pathogens. Since $\mathrm{CD} 4^{+} \mathrm{T}$-cell help is necessary for the development of essentially all aspects of the adaptive immune response, particularly primary responses, selective targeting of proliferating $\mathrm{CD} 4^{+} \mathrm{T}$ cells may be a fundamental mechanism involved in dampening the immune response to HIV, and the development of opportunistic infections. Moreover, since $\mathrm{CD} 4^{+} \mathrm{T}$ cells are well known for their role in providing critical signals during priming of cytotoxic $\mathrm{CD} 8^{+} \mathrm{T}$-lymphocyte (CTL) responses in vivo (161-163), loss of proliferating or regulatory $\mathrm{CD}^{+} \mathrm{T}$ cells may also be involved in the host failure to generate effective $\mathrm{CD} 8^{+} \mathrm{CTL}$ responses in HIV. In 
summary, the severe depletion of activated, memory, and dividing $\mathrm{CD} 4^{+} \mathrm{T}$ cells in early HIV/SIV infection likely play a central role in the immunopathogenesis of AIDS.

\section{T-follicular helper cells}

In the first steps of the humoral immune response to a new antigen, the antigen is captured by an antigen-presenting cell (APC) and transported to organized lymphoid tissues in lymph nodes, spleen, or GALT, through the mantle T-cell zone into the B-cell follicles, which initiates the activation and interaction of resident $\mathrm{T}$ and $\mathrm{B}$ cells, resulting in the germinal center (GC) reaction. GCs are discrete structures within the B-cell follicles of secondary lymphoid tissues in which the processes of somatic hypermutation of antibodies, immunoglobulin class switching, and affinity maturation of activated B cells occurs, resulting in the production of mature memory $\mathrm{B}$ cells, and antibody-secreting plasma cells $(164,165)$. For GCs to develop, B cells must first receive cognate help from specific CD4 ${ }^{+} \mathrm{T}$ helper cells named T-follicular helper (Tfh) cells, which reside within these follicles and are central to the development and regulation of primary humoral immune responses. Tfh cells are thus the crucial T-helper cell necessary for initiation and maintenance of GC responses that generate memory B cells and long-lived plasma cells (166-168). Tfh cells in humans and mice have been reported to express and produce regulatory molecules that facilitate their functional interactions with antigen-specific B cells, including the co-stimulatory molecule programmed death-1 (PD-1), inducible T-cell costimulator (ICOS), CXCR5, transcriptional factor B-cell lymphoma 6 (Bcl-6), and the cytokine IL-21, which promotes growth, differentiation, and class switching of B cells (169). In resistance to HIV infection and AIDS, binding antibodies, not just neutralizing antibodies, are now believed to be very important for protection from HIV infection, but the early effects of HIV infection on Tfhdependent humoral immune responses and the mechanisms behind the failure to develop adequate antibody responses are unknown. However, studies have demonstrated Tfh cells are expanded in lymph nodes in both HIV $(170)$ and SIV $(171,172)$ infection, and the recent finding of HIV DNA in Tfh of HIV infected humans, suggest TFH may be the major persistent reservoir for virus in HIV patients (173). Moreover, persistent infection of TFH may result in disruptions of B-cell development and antibody production, which may be still another mechanism by which HIV subverts the adaptive immune response.

\section{Virus-specific CD8+ T-cell and CTL responses in HIV}

CTLs are critical for protective immunity against many intracellular pathogens. In pathogenic HIV and SIV infection, the first CTL responses coincide with peak viremia, yet peak T-cell responses do not develop until 1-2 weeks after peak viremia $(137,174-176)$, suggesting the responses is 'too little and too late' to eliminate viral replication and to prevent systemic dissemination (177). Nonetheless, it is generally accepted that virusspecific $\mathrm{CD} 8^{+} \mathrm{T}$ lymphocytes play a central role in controlling HIV and SIV replication. Transient depletion of $\mathrm{CD} 8^{+}$lymphocytes in macaques in vivo, either on the day of challenge or in chronic infection, results in increased viral replication (178-180), confirming a critical role for $\mathrm{CD} 8^{+} \mathrm{T}$ cells in protection from SIV replication. During early HIV/SIV infection, CTL responses may provide more protection than antibodies, as neutralizing antibodies are produced much later. However, natural HIV infection escapes immune control in human and experimental models, despite variable, yet often strong CTL responses.

In SIV-infected macaques, virus-specific CTL responses are detectable as early as 12 days after experimental infection (181), but even at this early stage, virus has disseminated throughout the circulation and is well established in intestinal and lymphoid tissue reservoirs, and the immune system is unable to clear the infection (182). Virus-specific CTLs emerge in the intestine at the same time as in blood in SIV infection (181), and in 
chronic infection, percentages of CTLs are frequently higher in mucosal tissues compared to blood (183), suggesting most of the struggle for viral control occurs in the intestinal tract throughout the course of infection. Mucosal CTLs may play a role in limiting infection in mucosal tissues in HIV and SIV infection (184). However, they largely fail to control viral replication, as evidenced by persistence of virus and loss of target CD4 ${ }^{+} \mathrm{T}$ cells in GALT. HIV-specific CTLs have also been identified in cervical cytobrush cells from women who are repeatedly exposed to HIV, yet remain seronegative and apparently uninfected (185). Although highly controversial, this finding has been interpreted to suggest a protective role for mucosal CTLs in highly exposed, seronegative individuals (186).

The magnitude, function, and quality of CTL responses are likely to be important factors in the effectiveness of the cellular response. The ability of $\mathrm{CD} 8^{+} \mathrm{T}$ cells to contain infection may be associated with various factors, including intrinsic (i.e. TCR repertoire, polyfunctionality, regulatory molecules) and extrinsic (inflammatory microenvironment) factors associated with infection. The quality (polyfunctionality) of $\mathrm{CD} 8^{+} \mathrm{T}$-cell responses (measured by IFN- $\gamma$, IL-2, TNF- $a$, MIP- $1 \beta$ and CD107a) rather than the quantity has been shown to better correlate with control of viral replication in HIV nonprogressors and elite controllers (187). Following peak CTL responses in blood, viral sequences change dramatically with rapid selection of mutations. The earliest $\mathrm{T}$-cell responses are often specific for env, tat, and nef epitopes, whereas responses to other viral proteins, including more conserved Gag and Pol proteins, tend to arise during later waves of T-cell responses and may help maintain viral set point (188-191).

Memory $\mathrm{CD} 8^{+} \mathrm{T}$ cells are a major component of long-term immunity because of their longevity, and other unique properties including the ability to maintain a high proliferative potential to robustly expand upon secondary infection, when they rapidly re-express cytotoxic proteins and cytokines upon restimulation (192). During acute viral infection, naive $\mathrm{CD} 8^{+} \mathrm{T}$ cells respond to antigen by undergoing a pronounced clonal expansion during which a large number of antigen-specific T cells are generated (193). This initial expansion and acquisition of effector functions is followed by a contraction phase where the majority of the reactive $\mathrm{CD}^{+} \mathrm{T}$ cells undergo programmed cell death, leaving behind a small population of surviving effector and/or transitional memory cells, $(193,194)$. These memory subsets increase expression of IL-7Ra (IL-7Rahi) and lymphoid homing molecules such as CCR7, CXCR3, and CD62L, and gain the ability to produce IL-2. The enhanced secondary response can be attributed partly to the increased precursor frequency of antigen-specific cells but also to an altered responsiveness of the memory $\mathrm{CD}^{+} \mathrm{T}$ cells themselves, a process referred to as 'memory programming' (195). This programming depends on CD4 ${ }^{+}$ T-cell help and Th1-produced IL-2, because memory $\mathrm{CD} 8^{+} \mathrm{T}$ cells that are generated in the absence of MHC class II or IL-2 signaling are impaired in their ability to respond to subsequent challenge (193). During chronic viral infections, virus-specific CD8 ${ }^{+} \mathrm{T}$ cells undergo an altered pattern of differentiation and become 'exhausted'. CD8 ${ }^{+} \mathrm{T}$-cell exhaustion is a transcriptionally altered state of T-cell differentiation distinct from functional effector or memory $\mathrm{CD} 8^{+} \mathrm{T}$ cells (196). Exhausted $\mathrm{CD} 8^{+} \mathrm{T}$ cells undergo a hierarchical loss of function, ultimately resulting in virus-specific $\mathrm{CD}^{+} \mathrm{T}$ cells with severely compromised effector function, and in some cases these cells are physically deleted (197). Although the phenotypic definition of a protective CTL response is still lacking, considerable evidence indicates a major feature of an exhausted $\mathrm{CD}^{+} \mathrm{T}$-cell response is the sustained expression of multiple inhibitory receptors such as programmed death-1 (PD-1), B lymphocyte induced maturation protein-1 (Blimp-1), basic leucine transcription factor ATF-like (BATF), lymphocyte activation gene 3 (LAG3), 2B4, CD160, CTLA-4, PIR-B, GP49, and Tim-3 (196,198-200). Since CD4 ${ }^{+}$T-cell help is required for generation of primary CTL responses as well as in promoting protective $\mathrm{CD} 8^{+}$memory $\mathrm{T}$-cell development (161-163), impaired $\mathrm{CD} 8^{+} \mathrm{T}$-cell responses may be linked to the rapid depletion of effector $\mathrm{CD} 4^{+} \mathrm{T}$ cells. The 
rapid decline of $\mathrm{CD}^{+} \mathrm{T}$-cell responses is consistent with the impaired long-term $\mathrm{CD} 8^{+} \mathrm{T}$ cell memory that has been observed in $\mathrm{CD}^{+}{ }^{+} \mathrm{T}$-cell depleted murine models (163). Thus, continued infection and/or destruction of memory $\mathrm{CD} 4^{+} \mathrm{T}$-cell help be a major causal factor in the impaired or exhausted CD8 $8^{+}$CTL response described in HIV. In support of this idea, $\mathrm{CD} 4^{+}$lymphocyte-depleted macaques show similar peaks of viremia, do not manifest a postpeak decline of virus replication, and display rapid disease progression (201), suggesting $\mathrm{CD}^{+} \mathrm{T}$ cells play a major role in modulating early CTL responses. Thus, a weakened CD4 ${ }^{+}$ T-helper cell repertoire/response may provide suboptimal help for generating effective CTL responses.

Although virus-specific $\mathrm{CD} 8^{+} \mathrm{T}$ cells are clearly associated with some level of immune control, the fact that relatively large numbers of CTLs are detected in animals and humans that protect to AIDS, combined with the observation that CTL responses do not usually correlate with protection in vaccine studies or elite control, indicate other factors are likely to prove more effective in prevention strategies than CTL responses. There is some evidence that at least in blood of SIVmac-infected animals, levels of $\mathrm{CD}^{+} \mathrm{T}$-cell responses directly, rather than indirectly, correlate with viremia (unpublished observations). Further, higher env-specific CTL responses were detected in vaccinated persons who became infected with HIV in the AIDS/VAX vaccine trial (202), also calling into question the value of only testing $\mathrm{CD} 8^{+} \mathrm{T}$-cell responses in vaccine studies. At least in high-risk populations, it has been suggested that certain immunization strategies may boost pre-existing immune responses, due to pre-infection exposure, resulting in increased HIV susceptibility (202). Although the link between highly HIV exposed, seronegative persons and virus specific immune responses is still vague, it is likely that vaccines or possibly concurrent infections that trigger activation and proliferation of $\mathrm{CD} 4^{+} \mathrm{CCR} 5^{+}$cells may abrogate the effects of protection and may increase rates of transmission. Thus, continued and perhaps even more thorough pre-clinical testing of HIV vaccine candidates, in relevant animal models, clearly remains warranted.

\section{Innate lymphoid cells in HIV}

Mounting evidence suggests a role for innate immune cells, combined with specific antibody responses, in the control of HIV infection. Originally, non-T non-B lymphocytes (lineage negative) were simply termed natural killer (NK) cells based on their function and lack of receptors associated with other immune cell lineages. The term 'innate lymphoid cells' (ILCs) has now been proposed to include classical NK cells including a heterogeneous population of lineage negative cells in blood and mucosal tissues, which are further classified based upon their ability to produce type 1,2, and Th17 cell-associated cytokines (136). The non-T, non-B CD127 ${ }^{+} \mathrm{ROR} \gamma \mathrm{c}^{+}$populations include the lymphoid tissue inducer (LTi) cells as well as the NK receptor ${ }^{+}$LTi-like cells, which are distinct from conventional NK cells $(203,204)$. Interestingly, LTi are now believed to be identical to cells found in the small clusters of cells originally described in the small intestine of mice as 'cryptopatches' containing $\mathrm{CD} 3^{\text {neg }} \mathrm{CD} 4^{+}$cells, which are thought to be sites of extrathymic T-cell development $(205,206)$. We now know these cryptopatches contain clusters of $C D 4^{+} C D 3^{\text {neg }}$ LTi cells (Fig. 5), which are thought to be important for generation of new lymphoid follicles in the intestine (206).

ILCs as immune effector cells initiate immune responses to pathogens with the capacity to rapidly secrete effector cytokines, mediating interactions between ILCs, B and T cells (207). In addition to cytokine secretion, ILCs may directly modify adaptive B and T-cell responses via direct cell-to-cell interactions. Indeed, $\mathrm{ROR} \gamma \mathrm{t}^{+} \mathrm{ILCs}$ coordinate $\mathrm{T}$-cell independent $\mathrm{IgA}$ class switching via follicular DCs and plasma cell differentiation via DCs in ILFs (208). Clusters of LTi cells may have acquired additional signaling pathways including LT 
signaling, which provides the ability to recruit B cells that can then undergo T-cellindependent class switching and play a key role in the formation of lymphoid follicles in GALT. LTi cells, which coexpress the NK cell activating receptor NKp46 yet lack cytotoxic effectors such as granzymes or perforin, secrete IL-22, which initiate innate immune responses, and are thought to promote B and T-cell memory $(209,210)$.

In the intestine, ILCs mediate responses between host cells and commensal bacteria and play key roles in inflammation and tissue homeostasis $(207,211)$. Although ILCs do not express antigen-specific receptors like adaptive lymphocytes, they can produce (upon stimulation) several cytokines, which regulate the balance between protective immunity and destructive inflammation in the gut. Similar to Th17 cells, ILC17 cells are depleted in chronically SIVinfected macaques, which likely contributes to the loss of mucosal integrity $(153,212)$. However, the role of LTi and other ILCs are relatively unexplored in SIV/HIV infection. Due to the primary role of LTi cells in mucosal lymphoid tissue organogenesis, it may be beneficial to explore strategies to promote LTi cells or their function in the restoration of mucosal lymphoid tissue damage in HIV/SIV infection.

Classical NK cells are also involved in resistance to HIV infection and/or disease progression (213). The killer immunoglobulin-like receptors (KIRs) expressed on NK cells regulate the inhibition and activation of NK-cell responses through recognition of MHC class I molecules on target cells. Coexpression of specific MHC ligands and KIR are associated with slower disease progression. Specifically, the NK activating KIR3DS1 and KIR3DL1 receptors are associated with delayed progression to AIDS in individuals with HLA class I allotypes containing the 80Ile variant of the Bw4 motif52, which are thought to be ligands for these receptors $(213,214)$. Conceivably, KIR3DS1 mediates specific recognition of HIV-infected cells by NK cells, although the exact nature of the ligand is elusive. Nonetheless, these observations suggest an influence of interactions between KIR receptors and HLA-B alleles on the development and/or function of NK cells which may help to control viremia (137)

Although NK cells have an important role in defense against HIV-1, evasion mechanisms, such as nef-mediated downregulation of HLA-A and B molecules, are used by HIV-1 apparently to prevent T-cell recognition (215). However, the dominant KIR2D ligand, HLA$\mathrm{C}$ is relatively spared, suggesting there is a balance between T and NK cell evasion (213). Thus, downregulation of HLA molecules represents still another mechanism by which HIV has evolved to evade even the 'innate' host immune response.

\section{Humoral immune responses to HIV}

Converging data from various vaccine studies in humans and nonhuman primates are finally providing hints of what will be required for an effective vaccine capable of preventing HIV infection. Several antibodies have been identified that are capable of neutralizing most circulating HIV strains, including from the $1 \%$ of HIV elite controllers (216). However, it is becoming increasingly clear that defective antibody responses are the key to HIV gaining an irrevocable foothold on infection and perhaps persistence. In HIV and SIV infection, lymph nodes and GALT are reservoirs for viral persistence, even in patients on therapy or those controlling infection (217-219). Vigorous follicular hyperplasia in secondary lymphoid tissues (lymph nodes and GALT), are hallmarks of primary HIV/SIV infection, as B cells become activated, resulting in an increase in the size and number of lymphoid follicles, lymphadenopathy and immune activation. However, in chronic infection, there is generalized lymphoid depletion characterized by a reduction in GC size and number, which is eventually accompanied by fibrosis, and follicular involution with nearly complete destruction of the follicular architecture $(122,220,221)$. These changes have been shown to 
gradually result in an inability to mediate antigen-specific $\mathrm{T}$ helper cells and antibody responses in late stages of infection, contributing to $\operatorname{AIDS}(122,125,222)$. This is likely all the result of the early massive depletion of regulating $\mathrm{CD} 4^{+} \mathrm{T}$-cell subsets in the intestine and follicular networks. Consistently, progressive depletion of proliferating B cells and disruption of the follicular dendritic cell (FDC) network in germinal centers (GC) is evident in lymph nodes as early as 20 days after viral challenge of macaques $(125,223)$ and, as previously mentioned, HIV-infected humans within weeks of infection $(223,224)$. Thus, impairment of B cells and follicular T-helper cells in lymph nodes and GALT is consistent with undetectable, weak, and/or transient neutralizing antibody responses over the course of HIV/SIV infection (225-227).

The GALT is a major yet sometimes overlooked component of the humoral immune system. GALT is a major site for the production of antibodies and generation of antigen-specific CTLs (228). In fact, most of the immunoglobulin-produced daily by the body is IgA generated in the gut (Fig. 2). Locally produced IgA is released into the lumen, providing protection as a first line of defense against mucosal pathogens. Within the intestinal tract, mucosal IgA plays a crucial role in controlling microbial populations and mediating clearance of pathogens. Secretory IgA can neutralize pathogenic bacteria, control commensals and in general, is necessary for maintaining intestinal homeostasis. For example, IgA deficiency increases the risk for chronic giardiasis (229). Further, IgA production is regulated in GALT, which is highly dependent on the microbiota, and changes in the composition of the intestinal flora can alter the pattern of IgA production (230). TLR4 signals in the intestinal epithelium promote IgA production in the small intestine, by increasing B-cell recruitment and promoting class switching of B cells to IgA (89). Unlike $\operatorname{IgG}$ production, specific $\operatorname{IgA}$ responses lack typical memory characteristics, enabling changes in the specificity of $\operatorname{IgA}$ in response to shifts in the dominant intestinal microflora (230). Further, T-cell-independent IgA generation requires Tfh cells (231) and TGF- $\beta$ (232) generated in isolated lymphoid follicles in gut $(232,233)$. In summary, antigen captured by antigen-presenting cells in GALT initiates the activation and interactions of Tfh and B cells, the production of germinal centers, affinity maturation of B cells, and formation of antibodysecreting plasma cells (PCs) in the intestine. Although B cells do not appear to be directly infected in HIV/SIV infection, B cells are critically dependent on help from Tfh in GCs of follicles in GALT (and systemic lymphoid tissues), and thus infection or dysfunction of Tfh cells may play a key role in the B-cell dysregulation associated with HIV infection.

In HIV patients, the first detectable B-cell responses in blood occur by 8 days after exposure, and detectable antibodies to env glycoprotein 41 (gp41) do not appear in circulation until 13 days after the appearance of viremia (137). Production of env gp120specific antibodies is delayed for an additional 14 days, and antibodies that actually neutralize autologous virus in vitro develop even slower, arising $~ 12$ weeks or longer after HIV infection $(137,234,235)$. However, most patients do not develop broadly neutralizing antibody responses (bnAb) to HIV, and of those that do, many do not develop bnAb until 20-30 months after infection $(137,236)$. Further, evidence suggests the early, nonneutralizing antibodies may even mask key neutralizing epitopes, resulting in delayed or impaired neutralizing antibody responses (237).

The first HIV-1-specific IgA responses may be detected as early as 3 weeks after infection, and these antibodies are also directed against gp41 (137). Unlike intestinal secretions that contain mostly locally produced secretory $\operatorname{Ig}$ A (S-IgA), cervicovaginal fluid and semen contain more IgG than $\mathrm{IgA}$, and levels of immunoglobulins in the female genital tract are influenced by hormones (238). Both cervicovaginal secretions and semen contain plasmaderived as well as locally produced immunoglobulins, mainly of the $\operatorname{IgG}$ isotype $(239,240)$. 
Studies in the SIV macaque model have clearly shown antibodies play a role in protection against SIV transmission and disease progression. Intravenous and genital inoculation of SIV in rhesus macaques induced similar systemic humoral responses consisting mostly of IgG and detectable but lower levels of $\operatorname{IgA}$ and IgM (241). However, anti-SIV response in the vaginal washes consisted mainly of IgG with essentially no IgA or IgG plasma cells, and few IgM plasma cells, suggesting the mucosal immune system of the FRT is markedly impaired in chronic SIV infection (241). Intravenously administered antibodies (passive infusion studies) have been shown to protect macaques against intravenous or mucosal SHIV challenge (242). Topically applied antibodies can also protect macaques against vaginal SHIV challenge $(28,59,243)$. Considering their prime role in many successful vaccines in the past, antibody-based vaccines were the first choice in the initial stages of vaccine development.

Abundant evidence indicates that early and marked failures in B-cell development, especially in GALT, contribute to AIDS. In chronic infection and AIDS, B-cell development and responses are clearly impaired due to the collagen deposition and destruction of GCs in lymph nodes and GALT of SIV-infected macaques and HIV-infected humans (120, 126, 223). However, these deficits apparently starts very early in HIV infection, as half of the GC in the gut are lost within weeks of HIV infection $(223,224)$. Early loss of GCs and dysfunctional follicular $\mathrm{CD} 4^{+} \mathrm{T}$-helper cells may result in defects in the ability to rapidly generate high-affinity virus-specific binding antibodies and may lead to a delay in the induction of virus-neutralizing antibodies. Consistently, HIV-1 infection is associated with early class switching of polyclonal B cells and is associated with marked increases in the number of blood and tissue naive and memory B cells and plasma cells (137). In GALT, both HIV-1 and SIV is associated with apoptosis and lysis of follicular B cells. A rapid loss of Tfh and/or GC function may be responsible for the delay/inability of patients to develop effective neutralizing antibodies.

Although bnAbs can clearly prevent SIV transmission in passive infusion experiments, the inability to elicit sufficient levels of bnAb with vaccines, and perhaps more importantly, an inability to show correlations between protection and generation of bnAbs in vaccinated patients (see below) has increased attention on the role of binding yet non-neutralizing antibody responses. Antibodies that bind but do not neutralize HIV in tissue cultures may still impart antiviral effects through a variety of mechanisms including direct NK cell killing of infected cells, recruiting activated effector cells, which in turn induce cytolysis or apoptosis of infected cells, and or by mediating antibody-dependent cellular cytotoxicity (ADCC) by forming a complex between the IgG Fab portion of the antibody with the viral protein on the cell surface, and binding of the $\mathrm{Fc}$ portion to the receptor ( $\mathrm{Fc} \gamma \mathrm{Rs}$ ) on effector cells. Potential effector cells include NK cells, macrophages, dendritic cells, $\gamma \delta \mathrm{T}$ cells, and neutrophils. In addition to lysis, binding Fc $\gamma$ receptors can also lead to release of antiviral cytokines, which appear dependent on the specific receptor (239). Recent studies suggest that ADCC may play a major role in protection from infection or disease progression in vaccine models of HIV (see below), and such antibodies are increasingly emerging as a major correlate of immune protection in HIV infected controllers, and protected vaccinees.

\section{Vaccines and correlates of immunity}

Despite tremendous efforts, neither the development of an effective vaccine nor identification of consistent correlate(s) of immunity has been found for HIV. As we have attempted to illustrate throughout this article, this is mostly because, unlike virtually any other known pathogen encountered to date, HIV selectively targets and subverts essentially all components of the host immune system, particularly the major cells that initiate immune 
responses, allowing the virus to persist and replicate to high levels throughout the life of susceptible hosts, until the immune system completely collapses, resulting in AIDS.

Early phase 3 HIV vaccine efficacy trials tested recombinant HIV-1 envelope glycoprotein subunit (rgp120) that elicited antibody responses to env proteins, yet these vaccines showed no efficacy in protection from infection $(244,245)$. Since antibody responses to env provided no protection, the next generations of vaccine candidates focused on generating cellular (T cell) responses. However, the Merck STEP vaccine trial, which involved an adenoviral vector to deliver gag, nef, and pol peptides, also failed to provide protection from infection, despite detectable CTL responses in vaccines and may even have resulted in higher rates of infection in uncircumcised men with pre-existing immunity to the adenoviral vector (246). This reinforced concerns of using viral vaccine vectors in populations where the vectors were prevalent, as pre-existing immunity to the vectors may elicit immune activation/inflammation (247), which again may support rather than prevent HIV transmission/replication. A prior SIV vaccine study using recombinant varicella-zoster virus vaccine vectors expressing SIV env resulted in enhanced viral replication and disease progression in vaccinated macaques after SIVmac challenge (248), but it was not clear from the study precisely what immunologic mechanisms were responsible for the enhanced viral replication. Nonetheless these studies indicate that certain vaccines have the potential to be harmful, so thorough testing in relevant animals models remains a necessity.

A more recent HIV vaccine trial, however, finally provided some positive results, both in protection from infection and for demonstrating some correlates of protection. The Thai Phase III HIV vaccine clinical trial, also known as RV144, tested a 'prime-boost' combination of the two previously failed vaccines. This prime-boost vaccine combination lowered the rate of HIV infection by 31.2 percent in vaccinees compared to placebo controls (3). This was a surprising result, first because neither vaccine had proven effective alone but also because protection did not correlate with levels of HIV-specific CD8 ${ }^{+} \mathrm{T}$-cell responses or levels of bnAbs $(87,249)$. Interestingly, the vaccine did elicit proliferative $\mathrm{CD} 4^{+} \mathrm{T}$-cell responses and the production of binding antibodies to the V1/V2 region of env $(3,87)$, the latter correlating with protection. Furthermore, the vast majority of vaccines demonstrated strong ADCC activity, suggesting the binding antibodies may have been involved in mediating protection through this mechanism (250). However, in patients who became infected after receiving the vaccine, no difference in viremia or levels of viral control was detected, indicating the vaccine had minimal effects on viral replication after transmission. Although the level of efficacy was not sufficient to advance this vaccine to the general population, the results suggest that if sufficient levels of antibodies against specific regions of the HIV envelope can be elicited, protection from a vaccine may be possible (3).

Several other vaccine candidates in nonhuman primate models are showing remarkable efficacy in either preventing or resisting vaginal SIV/SHIV transmission to macaques, or in reducing viral loads after infection, and in some cases, possibly clearance of infection through vaccination, suggesting a cure may also some day be possible (251). Decades ago, it was demonstrated that vaccination (or infection) with attenuated, live strains of SIV lacking one or more genes essential for pathogenicity could result in what appears to be sterilizing immunity against homologous challenge with pathogenic SIV $(252,253)$. However, the possibility of reversion to pathogenicity renders the LAV approach less desirable for a vaccination strategy. Nonetheless, these vaccines have provided important information on the correlates of immunity that a vaccine needs to induce. For example, the LAV SIV $\Delta$-nef, which was originally shown to confer protection against pathogenic challenge, was also recently shown to elicit potent ADCC activity, in the absence of neutralizing antibodies, again suggesting binding antibodies mediating innate immune responses may play a significant role in protection (254). Further studies demonstrated that LAV protection 
correlated with virus-specific $\mathrm{CD} 4^{+}$and $\mathrm{CD} 8^{+} \mathrm{T}$-cell responses in lymph nodes rather than blood, likely due to the persistence of LAV (antigenic persistence) in the Tfh of GCs (255).

A vaccination strategy using replicating adenovirus type 5 HIV/SIV recombinants has also shown significant protection against SHIV challenge (256), which was also mediated through NK mediated mechanisms (257) and also correlated with virus specific mucosal IgA responses (258). Further, low levels of neutralizing antibodies and env-specific CD4 ${ }^{+} \mathrm{T}$-cell responses have been correlated with protection against SIVsmE660 challenge in DNA prime/adenoviral (259) prime followed by replication-defective lymphocytic choriomeningitis virus (rLCMV) boost strategies (260). Several other vaccine or challenge studies in rhesus macaques have shown that ADDC/ADCVI activity correlates with reduced viral load post challenge (261-264), and thus converging evidence from both human and macaque studies suggest that binding antibodies that elicit ADCC activity may best correlate with protection from HIV infection and disease progression.

Vaccination using SIV protein-encoding vectors based on rhesus cytomegalovirus (RhCMV) specifically to induce durable effector memory $\mathrm{T}$-cell responses demonstrated resistance to SIVmac239 infection and control of infection after repeated rectal challenge (251). Although animals did not show sterilizing immunity, only transient low level blips of virus were detected, and mucosal and memory $\mathrm{CD}^{+} \mathrm{T}$ cells were spared, indicating a remarkable level of protection. Further, in many of the vaccinated animals, virus cannot be detected in blood or tissues by current technologies, even in the face of experimental CD8 ${ }^{+} \mathrm{T}$-cell depletion, suggesting these animals may have completely cleared the infection (87). Thus, in addition to ADCC activity, preservation of memory $\mathrm{CD} 4^{+} \mathrm{T}$ cells and perhaps virus-specific $\mathrm{CD}^{+}{ }^{+} \mathrm{T}$-cell responses are other major correlates of protection that will be required from an effective vaccine.

\section{The case for CD4+ $T$ cells in protection from HIV}

Although to this point we have discussed $\mathrm{CD}^{+}{ }^{+} \mathrm{T}$-cell subsets as the major targets for viral replication, it is increasingly apparent that, in addition to the innate responses above, virus specific $\mathrm{CD}^{+} \mathrm{T}$-cell responses are emerging as a major correlate of immunity in vaccinated protected subsets, and elite controllers. Several recent studies have demonstrated CD4 ${ }^{+} \mathrm{T}$ cells may be the most important component of an effective antiviral response (265-267), and differences in the breadth of $\mathrm{CD} 4^{+} \mathrm{T}$-cell profiles correlate with control of viremia in HIV patients (268). Expansion of viral specific $\mathrm{CD} 4^{+} \mathrm{T}$ cells has recently been demonstrated to be a much better predictor of control of viremia than $\mathrm{CD} 8^{+} \mathrm{T}$ cells in both hepatitis infection of chimpanzees (269) and HIV infection of humans (266). In fact, expansion of cytolytic $\mathrm{CD}^{+} \mathrm{T}$ cells bearing perforin and granzymes best correlates with control of HIV infection. Further, this control was not associated with specific MHC alleles such as HLA-B27 or HLA-B57, which are often associated with spontaneous control of HIV (270). This is particularly exciting, as it suggests an immunologic mechanism that may be manipulated to make 'susceptible' populations resistant to HIV infection.

Numerous studies of HIV and SIV have also shown an association between control of viremia and $\mathrm{CD}^{+}{ }^{+} \mathrm{T}$-cell responses, which can kill HIV/SIV-infected macrophages $(201,271,272)$. Thus, we predict that virus-specific CD $4^{+} \mathrm{T}$-cell response will emerge as a much better correlate of protection fro infection and possibly even clearance of HIV from infected patients. However, distinguishing the proper mechanism for eliciting the appropriate $\mathrm{CD}^{+} \mathrm{T}$-cell response will be key, as we must first distinguish the elements of a protective response from a $\mathrm{CD} 4^{+} \mathrm{T}$-cell activation response that actually facilitates infection and disease progression. 
One key that suggests a link between the protective $\mathrm{CD} 4^{+} \mathrm{T}$-cell response and effective 'innate' ADCC responses is the importance of proper CD4+ $\mathrm{T}$-cell help in B-cell development and 'programming'. For example, persistence of antigen (and not lytic virus) within GCs and the proper stimulation of Tfh cells to generate, promote, and mature B-cell responses into effective plasma cells secreting appropriately programmed/matured antibodies (referred to as somatic hypermutation) might distinguish protection from progression to disease. Conceivably, the persistence of antigen in proximity to Tfh cells, and appropriate activation of Tfh to provide proper B-cell programming and somatic hypermutation may play key roles in the development of protective immunity. This hypothesis unifies many of the correlates of immunity to date, including the previously demonstrated need for antigenic persistence in lymph nodes (LAV and various vaccine studies), correlations of virus specific $\mathrm{CD}^{+}$and $\mathrm{CD} 8^{+} \mathrm{T}$-cell responses in lymph nodes (but not blood) and generation of effective ADCC antibodies in protected vaccines and spontaneous controllers, combined with the findings of preserved $\mathrm{CD} 4^{+} \mathrm{T}$-cell subsets and ILCs (IL17 etc.) in tissues of nonprogressing hosts. Although much work remains in deciphering how to appropriately stimulate effective $\mathrm{CD} 4^{+} \mathrm{T}$-cell responses, without eliciting additional target cells for HIV, at least we now have clues for what immunologic responses will be necessary for an effective vaccine or therapy.

\section{Conclusions and future directions}

In susceptible hosts (macaques and humans), SIV/HIV selectively infects and destroys activated, memory $\mathrm{CD} 4{ }^{+} \mathrm{CCR}^{+} \mathrm{T}$ cells, which are the orchestrating cell of the immune system, which are recruited to early sites of pathogen exposure/infection, to facilitate effective immune responses against most pathogens. Thus, most of the innate and adaptive immune responses simply provide additional fuel for viral persistence and replication. Further, despite being classified as 'lentiviruses' (slow viruses), SIV/HIV rapidly stimulates local immune responses that allow local expansion and systemic spread of transmitted founder virus (TFV) to the intestine, where abundant target cells support marked, early, and high levels of viral replication (peak viremia). Since HIV has such a high rate of mutation, this results in rapid and tremendous viral diversity and emergence of viral variants that are already capable of evading the slowly emerging cellular and humoral immune responses developing in response to the TFV. Infection and dysregulation of key mucosal CD4 $4^{+} \mathrm{T}$-cell subsets leads to intestinal barrier damage and subsequent HIV-specific and nonspecific systemic immune activation stimulate continual production of new effector $\mathrm{CD} 4^{+} \mathrm{CCR} 5^{+} \mathrm{T}$ cells, providing a continual source of target cells to support sustained replication throughout host tissues. Finally, the HIV genome encodes for a variety of proteins that evade immune responses, including those that downregulate key host immunoregulatory molecules on cells and bind or inactivate the effects of host proteins or antimicrobials generated in what was intended as a 'protective' response to infection, thus limiting essentially all components of the host immune response to control HIV infection.

Decades of study of the immunology and pathogenesis of HIV infections have taught us more about human immunology and host defense than perhaps any other disease in history, yet with a pathogen so complex and cleverly evolved to thwart all major components of the human immune response, it is no wonder it has been so difficult to produce an effective vaccine for HIV. Nonetheless, after decades of failure, persistence in vaccine research is finally paying off, as we have achieved modest success in preventing HIV infections through a partially effective vaccine, and more importantly, we are finally beginning to understand at least some of the correlates of immunity generated by protected vaccines. In addition, remarkable successes are emerging from new vaccine strategies in nonhuman primate models, which may pave the way for more effective vaccines in the near future. As vaccine research begins to finally show promise rather than failure, and correlates of innate 
and adaptive immune responses that may prevent infection, or even purge HIV from infected hosts, we may at least hope that an effective vaccine will finally be forthcoming in the near future.

\section{Acknowledgments}

We thank Terri Rasmussen, Megan Gardner, and Meagan Watkins for editorial and technical assistance, and Xavier Alvarez for confocal microscopy support. This work was supported in part by NIH grants R01 AI084793, the National Center for Research Resources, and the Office of Research Infrastructure Programs (ORIP) of the National Institutes of Health through grant no. OD011104-51.

\section{References}

1. Granich R, Williams B, Montaner J. Fifteen million people on antiretroviral treatment by 2015: treatment as prevention. Curr Opin HIV AIDS. 2013; 8:41-49. [PubMed: 23188178]

2. Shattock RJ, Warren M, McCormack S, Hankins CA. AIDS. Turning the tide against HIV. Science. 2011; 333:42-43. [PubMed: 21719662]

3. Haynes BF, et al. Immune-correlates analysis of an HIV-1 vaccine efficacy trial. N Engl J Med. 2012; 366:1275-1286. [PubMed: 22475592]

4. Rerks-Ngarm S, et al. Vaccination with ALVAC and AIDSVAX to prevent HIV-1 infection in Thailand. N Engl J Med. 2009; 361:2209-2220. [PubMed: 19843557]

5. Mofenson LM. Interaction between timing of perinatal human immunodeficiency virus infection and the design of preventive and therapeutic interventions. Acta Paediatr Suppl. 1997; 421:1-9. [PubMed: 9240849]

6. Ruprecht RM, et al. Oral transmission of primate lentiviruses. J Infect Dis. 1999; 179(Suppl):S408412. [PubMed: 10099108]

7. Ruprecht RM, et al. Oral SIV, SHIV, and HIV type 1 infection. AIDS Res Hum Retroviruses. 1998; 14(Suppl):S97-103. [PubMed: 9581893]

8. Miclat NN, Hodgkinson R, Marx GF. Neonatal gastric pH. Anesth Analg. 1978; 57:98-101. [PubMed: 24375]

9. Miller CJ, et al. Genital mucosal transmission of simian immunodeficiency virus: animal model for heterosexual transmission of human immunodeficiency virus. J Virol. 1989; 63:4277-4284. [PubMed: 2778875]

10. Ma ZM, Keele BF, Qureshi H, Stone M, Desilva V, Fritts L, Lifson JD, Miller CJ. SIVmac251 is inefficiently transmitted to rhesus macaques by penile inoculation with a single SIVenv variant found in ramp-up phase plasma. AIDS Res Hum Retroviruses. 2011; 27:1259-1269. [PubMed: 21732792]

11. Miller CJ, Shattock RJ. Target cells in vaginal HIV transmission. Microbes Infect. 2003; 5:59-67. [PubMed: 12593974]

12. Marx PA, et al. Progesterone implants enhance SIV vaginal transmission and early virus load. Nat Med. 1996; 2:1084-1089. [PubMed: 8837605]

13. Veazey RS, Shattock RJ, Klasse PJ, Moore JP. Animal models for microbicide studies. Curr HIV Res. 2012; 10:79-87. [PubMed: 22264049]

14. Heffron R, et al. Use of hormonal contraceptives and risk of HIV-1 transmission: a prospective cohort study. Lancet Infect Dis. 2012; 12:19-26. [PubMed: 21975269]

15. Wira CR, Patel MV, Ghosh M, Mukura L, Fahey JV. Innate immunity in the human female reproductive tract: endocrine regulation of endogenous antimicrobial protection against HIV and other sexually transmitted infections. Am J Reprod Immunol. 2011; 65:196-211. [PubMed: 21294805]

16. Li Q, Estes JD, et al. Glycerol monolaurate prevents mucosal SIV transmission. Nature. 2009; 458:1034-1038. [PubMed: 19262509]

17. Hughes JP, et al. Determinants of per-coital-act HIV-1 infectivity among African HIV-1serodiscordant couples. J Infect Dis. 2012; 205:358-365. [PubMed: 22241800] 
18. Shukair SA, et al. Human cervicovaginal mucus contains an activity that hinders HIV-1 movement. Mucosal Immunol. 2013; 6:427-434. [PubMed: 22990624]

19. Mauck CK, et al. The effect of one injection of Depo-Provera on the human vaginal epithelium and cervical ectopy. Contraception. 1999; 60:15-24. [PubMed: 10549448]

20. Poonia B, Walter L, Dufour J, Harrison R, Marx PA, Veazey RS. Cyclic changes in the vaginal epithelium of normal rhesus macaques. J Endocrinol. 2006; 190:829-835. [PubMed: 17003283]

21. Ma Z, Lu FX, Torten M, Miller CJ. The number and distribution of immune cells in the cervicovaginal mucosa remain constant throughout the menstrual cycle of rhesus macaques. Clin Immunol. 2001; 100:240-249. [PubMed: 11465954]

22. Poonia B, Wang X, Veazey RS. Distribution of simian immunodeficiency virus target cells in vaginal tissues of normal rhesus macaques: implications for virus transmission. J Reprod Immunol. 2006; 72:74-84. [PubMed: 16956666]

23. Sodora DL, Gettie A, Miller CJ, Marx PA. Vaginal transmission of SIV: assessing infectivity and hormonal influences in macaques inoculated with cell-free and cell-associated viral stocks. AIDS Res Human Retroviruses. 1998; 14(Suppl):S119-123. [PubMed: 9581895]

24. Vishwanathan SA, et al. High susceptibility to repeated, low-dose, vaginal SHIV exposure late in the luteal phase of the menstrual cycle of pigtail macaques. J Acquir Immune Defic Syndr. 2011; 57:261-264. [PubMed: 21546848]

25. Marx PA, et al. Progesterone implants enhance SIV vaginal transmission and early virus load. Nat Med. 1996; 2:1084-1089. [PubMed: 8837605]

26. Wira CR, Fahey JV, Abrahams VM, Rossoll RM. Influence of stage of the reproductive cycle and estradiol on thymus cell antigen presentation. J Steroid Biochem Mol Biol. 2003; 84:79-87. [PubMed: 12648527]

27. Wira CR, Fahey JV, Sentman CL, Pioli PA, Shen L. Innate and adaptive immunity in female genital tract: cellular responses and interactions. Immunol Rev. 2005; 206:306-335. [PubMed: 16048557]

28. Mascola JR, et al. Protection of macaques against vaginal transmission of a pathogenic HIV-1/SIV chimeric virus by passive infusion of neutralizing antibodies. Nat Med. 2000; 6:207-210. [PubMed: 10655111]

29. Veazey RS, et al. Use of a small molecule CCR5 inhibitor in macaques to treat simian immunodeficiency virus infection or prevent simian-human immunodeficiency virus infection. $\mathrm{J}$ Exp Med. 2003; 198:1551-1562. [PubMed: 14623909]

30. Veazey RS, et al. Prevention of virus transmission to macaque monkeys by a vaginally applied monoclonal antibody to HIV gp120. Nature Med. 2003; 9:343-346. [PubMed: 12579198]

31. Hu J, Gardner MB, Miller CJ. Simian immunodeficiency virus rapidly penetrates the cervicovaginal mucosa after intravaginal inoculation and infects intraepithelial dendritic cells. $\mathrm{J}$ Virol. 2000; 74:6087-6095. [PubMed: 10846092]

32. Hu J, Pope M, Brown C, O’Doherty U, Miller CJ. Immunophenotypic characterization of simian immunodeficiency virus-infected dendritic cells in cervix, vagina, and draining lymph nodes of rhesus monkeys. Lab Invest. 1998; 78:435-451. [PubMed: 9564888]

33. Hussain LA, Lehner T. Comparative investigation of Langerhans' cells and potential receptors for HIV in oral, genitourinary and rectal epithelia. Immunology. 1995; 85:475-484. [PubMed: 7558138]

34. Bjercke S, Scott H, Braathen LR, Thorsby E. HLA-DR-expressing Langerhans'-like cells in vaginal and cervical epithelium. Acta Obstetricia et Gynecologica Scandinavica. 1983; 62:585589. [PubMed: 6367339]

35. Morris HH, Gatter KC, Stein H, Mason DY. Langerhans' cells in human cervical epithelium: an immunohistological study. Br J Obstet Gyn. 1983; 90:400-411.

36. Turville SG, et al. Immunodeficiency virus uptake, turnover, and 2-phase transfer in human dendritic cells. Blood. 2004; 103:2170-2179. [PubMed: 14630806]

37. Miller CJ, McChesney M, Moore PF. Langerhans cells, macrophages, and lymphocyte subsets in the cervix and vagina of rhesus macaques. Lab Invest. 1992; 67:628-634. [PubMed: 1434540]

38. Geijtenbeek TB, et al. DC-SIGN, a dendritic cell-specific HIV-1-binding protein that enhances trans-infection of T cells. Cell. 2000; 100:587-597. [PubMed: 10721995] 
39. Turville SG, Cameron PU, Handley A, Lin G, Pohlmann S, Doms RW, Cunningham AL. Diversity of receptors binding HIV on dendritic cell subsets. Nat Immunol. 2002; 3:975-983. [PubMed: 12352970]

40. Baribaud F, Pohlmann S, Doms RW. The role of DC-SIGN and DC-SIGNR in HIV and SIV attachment, infection, and transmission. Virology. 2001; 286:1-6. [PubMed: 11448153]

41. Hu Q, et al. Blockade of attachment and fusion receptors inhibits HIV-1 infection of human cervical tissue. J Exp Med. 2004; 199:1065-1075. [PubMed: 15078900]

42. Parr MB, Kepple L, Parr EL. Antigen recognition in the female reproductive tract. II. Endocytosis of horseradish peroxidase by Langerhans cells in murine vaginal epithelium. Biology Reprod. 1991; 45:261-265.

43. Veazey RS, Marx PA, Lackner AA. Vaginal CD4+ T cells express high levels of CCR5 and are rapidly depleted in simian immunodeficiency virus infection. J Infect Dis. 2003; 187:769-776. [PubMed: 12599050]

44. Haase AT. Early events in sexual transmission of HIV and SIV and opportunities for interventions. Annu Rev Med. 2011; 62:127-139. [PubMed: 21054171]

45. Shattock RJ, Moore JP. Inhibiting sexual transmission of HIV-1 infection. Nat Rev Microbiol. 2003; 1:25-34. [PubMed: 15040177]

46. Miller CJ, et al. Propagation and dissemination of infection after vaginal transmission of simian immunodeficiency virus. J Virol. 2005; 79:9217-9227. [PubMed: 15994816]

47. Zhang Z, et al. Sexual transmission and propagation of SIV and HIV in resting and activated CD4+ T cells. Science. 1999; 286:1353-1357. [PubMed: 10558989]

48. Salazar-Gonzalez JF, et al. Genetic identity, biological phenotype, and evolutionary pathways of transmitted/founder viruses in acute and early HIV-1 infection. J Exp Med. 2009; 206:1273-1289. [PubMed: 19487424]

49. Keele BF, Derdeyn CA. Genetic and antigenic features of the transmitted virus. Curr Opin HIV AIDS. 2009; 4:352-357. [PubMed: 20048697]

50. Blaskewicz CD, Pudney J, Anderson DJ. Structure and function of intercellular junctions in human cervical and vaginal mucosal epithelia. Biol Reprod. 2011; 85:97-104. [PubMed: 21471299]

51. Pandrea I, et al. Mucosal simian immunodeficiency virus transmission in African green monkeys: susceptibility to infection is proportional to target cell availability at mucosal sites. J Virol. 2012; 86:4158-4168. [PubMed: 22318138]

52. Keele BF, et al. Identification and characterization of transmitted and early founder virus envelopes in primary HIV-1 infection. Proc Natl Acad Sci USA. 2008; 105:7552-7557. [PubMed: 18490657]

53. Hladik F, et al. Initial events in establishing vaginal entry and infection by human immunodeficiency virus type-1. Immunity. 2007; 26:257-270. [PubMed: 17306567]

54. Veazey RS, et al. Protection of macaques from vaginal SHIV challenge by vaginally delivered inhibitors of virus-cell fusion. Nature. 2005; 438:99-102. [PubMed: 16258536]

55. Veazey RS, et al. Tropism-independent protection of macaques against vaginal transmission of three SHIVs by the HIV-1 fusion inhibitor T-1249. Proc Natl Acad Sci USA. 2008; 105:1053110536. [PubMed: 18647836]

56. Veazey RS, et al. Protection of rhesus macaques from vaginal infection by vaginally delivered maraviroc, an inhibitor of HIV-1 entry via the CCR5 co-receptor. J Infect Dis. 2010; 202:739-744. [PubMed: 20629537]

57. Veazey RS, et al. Topically applied recombinant chemokine analogues fully protect macaques from vaginal simian-human immunodeficiency virus challenge. J Infect Dis. 2009; 199:15251527. [PubMed: 19331577]

58. Lederman MM, et al. Prevention of vaginal SHIV transmission in rhesus macaques through inhibition of CCR5. Science. 2004; 306:485-487. [PubMed: 15486300]

59. Veazey RS, et al. Prevention of virus transmission to macaque monkeys by a vaginally applied monoclonal antibody to HIV-1 gp120. Nat Med. 2003; 9:343-346. [PubMed: 12579198]

60. Schust DJ, Quayle AJ, Amedee AM. Mucosal co-infections and HIV-1 transmission and pathogenesis. Curr HIV Res. 2012; 10:195-201. [PubMed: 22497695] 
61. Cohen CR, et al. Increased interleukin-10 in the the endocervical secretions of women with nonulcerative sexually transmitted diseases: a mechanism for enhanced HIV-1 transmission? AIDS. 1999; 13:327-332. [PubMed: 10199222]

62. Mayer KH, Venkatesh KK. Interactions of HIV, other sexually transmitted diseases, and genital tract inflammation facilitating local pathogen transmission and acquisition. Am J Reprod Immunol. 2011; 65:308-316. [PubMed: 21214660]

63. Schust DJ, et al. Potential mechanisms for increased HIV-1 transmission across the endocervical epithelium during C. Curr HIV Res. 2012; 10:218-227. [PubMed: 22384841]

64. Jameson B, et al. Expression of DC-SIGN by dendritic cells of intestinal and genital mucosae in humans and rhesus macaques. J Virol. 2002; 76:1866-1875. [PubMed: 11799181]

65. Bhoopat L, et al. In vivo identification of Langerhans and related dendritic cells infected with HIV-1 subtype E in vaginal mucosa of asymptomatic patients. Mod Pathol. 2001; 14:1263-1269. [PubMed: 11743049]

66. Takeuchi O, Akira S. Pattern recognition receptors and inflammation. Cell. 2010; 140:805-820. [PubMed: 20303872]

67. Srikrishna G, Freeze HH. Endogenous damage-associated molecular pattern molecules at the crossroads of inflammation and cancer. Neoplasia. 2009; 11:615-628. [PubMed: 19568407]

68. Mogensen TH, Melchjorsen J, Larsen CS, Paludan SR. Innate immune recognition and activation during HIV infection. Retrovirology. 2010; 7:54. [PubMed: 20569472]

69. Pivarcsi A, et al. Microbial compounds induce the expression of pro-inflammatory cytokines, chemokines and human beta-defensin-2 in vaginal epithelial cells. Microbes Infect. 2005; 7:11171127. [PubMed: 15893496]

70. Herbst-Kralovetz MM, et al. Quantification and comparison of toll-like receptor expression and responsiveness in primary and immortalized human female lower genital tract epithelia. Am J Reprod Immunol. 2008; 59:212-224. [PubMed: 18201283]

71. Han JH, et al. Modulation of human beta-defensin- 2 expression by 17 beta-estradiol and progesterone in vaginal epithelial cells. Cytokine. 2010; 49:209-214. [PubMed: 19819163]

72. Cole AM, Cole AL. Antimicrobial polypeptides are key anti-HIV-1 effector molecules of cervicovaginal host defense. Am J Reprod Immunol. 2008; 59:27-34. [PubMed: 18154593]

73. Rancez M, Couedel-Courteille A, Cheynier R. Chemokines at mucosal barriers and their impact on HIV infection. Cytokine Growth Factor Rev. 2012; 23:233-243. [PubMed: 22728258]

74. Cremel M, et al. Characterization of CCL20 secretion by human epithelial vaginal cells: involvement in Langerhans cell precursor attraction. J Leukoc Biol. 2005; 78:158-166. [PubMed: 15831560]

75. Dieu-Nosjean MC, et al. Macrophage inflammatory protein 3alpha is expressed at inflamed epithelial surfaces and is the most potent chemokine known in attracting Langerhans cell precursors. J Exp Med. 2000; 192:705-718. [PubMed: 10974036]

76. Wang Y, Abel K, Lantz K, Krieg AM, McChesney MB, Miller CJ. The Toll-like receptor 7 (TLR7) agonist, imiquimod, and the TLR9 agonist, CpG ODN, induce antiviral cytokines and chemokines but do not prevent vaginal transmission of simian immunodeficiency virus when applied intravaginally to rhesus macaques. J Virol. 2005; 79:14355-14370. [PubMed: 16254370]

77. de Jong MA, de Witte L, Oudhoff MJ, Gringhuis SI, Gallay P, Geijtenbeek TB. TNF-alpha and TLR agonists increase susceptibility to HIV-1 transmission by human Langerhans cells ex vivo. J Clin Invest. 2008; 118:3440-3452. [PubMed: 18776939]

78. Abel K, Rocke DM, Chohan B, Fritts L, Miller CJ. Temporal and anatomic relationship between virus replication and cytokine gene expression after vaginal simian immunodeficiency virus infection. J Virol. 2005; 79:12164-12172. [PubMed: 16160143]

79. Shacklett BL, Anton PA. HIV Infection and Gut Mucosal Immune Function: Updates on Pathogenesis with Implications for Management and Intervention. Curr Infect Dis Rep. 2010; 12:19-27. [PubMed: 20174448]

80. Ling B, Mohan M, Lackner AA, Green LC, Marx PA, Doyle LA, Veazey RS. The large intestine as a major reservoir for simian immunodeficiency virus in macaques with long-term, nonprogressing infection. J Infect Dis. 2010; 202:1846-1854. [PubMed: 21050120] 
81. Veazey RS, Marx PA, Lackner AA. The mucosal immune system: primary target for HIV infection and AIDS. Trends Immunol. 2001; 22:626-633. [PubMed: 11698224]

82. Veazey RS, et al. Gastrointestinal tract as a major site of CD4+ T cell depletion and viral replication in SIV infection. Science. 1998; 280:427-431. [PubMed: 9545219]

83. Smit-McBride Z, Mattapallil JJ, McChesney M, Ferrick D, Dandekar S. Gastrointestinal T lymphocytes retain high potential for cytokine responses but have severe CD4+ T-cell depletion at all stages of simian immunodeficiency virus infection compared to peripheral lymphocytes. $\mathrm{J}$ Virol. 1998; 72:6646-6656. [PubMed: 9658111]

84. Guadalupe M, Reay E, Sankaran S, Prindiville T, Flamm J, McNeil A, Dandekar S. Severe CD4+ T-cell depletion in gut lymphoid tissue during primary human immunodeficiency virus type 1 infection and substantial delay in restoration following highly active antiretroviral therapy. J Virol. 2003; 77:11708-11717. [PubMed: 14557656]

85. Brenchley JM, et al. CD4+ T cell depletion during all stages of HIV disease occurs predominantly in the gastrointestinal tract. J Exp Med. 2004; 200:749-759. [PubMed: 15365096]

86. Mattapallil JJ, Douek DC, Hill B, Nishimura Y, Martin M, Roederer M. Massive infection and loss of memory CD4+ T cells in multiple tissues during acute SIV infection. Nature. 2005; 434:10931097. [PubMed: 15793563]

87. Picker LJ, Hansen SG, Lifson JD. New paradigms for HIV/AIDS vaccine development. Annu Rev Med. 2012; 63:95-111. [PubMed: 21942424]

88. Fukata M, Vamadevan AS, Abreu MT. Toll-like receptors (TLRs) and Nod-like receptors (NLRs) in inflammatory disorders. Semin Immunol. 2009; 21:242-253. [PubMed: 19748439]

89. Shang L, et al. Toll-like receptor signaling in small intestinal epithelium promotes B-cell recruitment and IgA production in lamina propria. Gastroenterology. 2008; 135:529-538. [PubMed: 18522803]

90. Cario E, Gerken G, Podolsky DK. Toll-like receptor 2 enhances ZO-1-associated intestinal epithelial barrier integrity via protein kinase C. Gastroenterology. 2004; 127:224-238. [PubMed: 15236188]

91. Girardin SE, et al. Nod1 detects a unique muropeptide from gram-negative bacterial peptidoglycan. Science. 2003; 300:1584-1587. [PubMed: 12791997]

92. Bouskra D, et al. Lymphoid tissue genesis induced by commensals through NOD1 regulates intestinal homeostasis. Nature. 2008; 456:507-510. [PubMed: 18987631]

93. Stecher B, et al. Salmonella enterica serovar typhimurium exploits inflammation to compete with the intestinal microbiota. PLoS Biol. 2007; 5:2177-2189. [PubMed: 17760501]

94. Endt K, et al. The microbiota mediates pathogen clearance from the gut lumen after non-typhoidal Salmonella diarrhea. PLoS Pathog. 2010; 6:e1001097. [PubMed: 20844578]

95. Simmons CP, et al. Central role for B lymphocytes and CD4+ T cells in immunity to infection by the attaching and effacing pathogen Citrobacter rodentium. Infect Immun. 2003; 71:5077-5086. [PubMed: 12933850]

96. Zheng Y, et al. Interleukin-22 mediates early host defense against attaching and effacing bacterial pathogens. Nat Med. 2008; 14:282-289. [PubMed: 18264109]

97. Harrison OJ, Maloy KJ. Innate immune activation in intestinal homeostasis. J Innate Immun. 2011; 3:585-593. [PubMed: 21912101]

98. Blaschitz C, Raffatellu M. Th17 cytokines and the gut mucosal barrier. J Clin Immunol. 2010; 30:196-203. [PubMed: 20127275]

99. Neutra MR, Kozlowski PA. Mucosal vaccines: the promise and the challenge. Nat Rev Immunol. 2006; 6:148-158. [PubMed: 16491139]

100. Veazey R, Lackner A. The mucosal immune system and HIV-1 infection. AIDS Rev. 2003; 5:245-252. [PubMed: 15012003]

101. Veazey RS, Mansfield KG, Tham IC, Carville AC, Shvetz DE, Forand AE, Lackner AA. Dynamics of CCR5 expression by CD4(+) T cells in lymphoid tissues during simian immunodeficiency virus infection. J Virol. 2000; 74:11001-11007. [PubMed: 11069995]

102. Fauci AS, Pantaleo G, Stanley S, Weissman D. Immunopathogenic mechanisms of HIV infection. Ann Intern Med. 1996; 124:654-663. [PubMed: 8607594] 
103. Deeks SG, Walker BD. The immune response to AIDS virus infection: good, bad, or both? J Clin Invest. 2004; 113:808-810. [PubMed: 15067312]

104. Giorgi JV, et al. Predictive value of immunologic and virologic markers after long or short duration of HIV-1 infection. J Acquir Immune Defic Syndr. 2002; 29:346-355. [PubMed: 11917238]

105. Silvestri G, et al. Nonpathogenic SIV infection of sooty mangabeys is characterized by limited bystander immunopathology despite chronic high-level viremia. Immunity. 2003; 18:441-452. [PubMed: 12648460]

106. Silvestri G, Paiardini M, Pandrea I, Lederman MM, Sodora DL. Understanding the benign nature of SIV infection in natural hosts. J Clin Invest. 2007; 117:3148-3154. [PubMed: 17975656]

107. Kornfeld C, et al. Antiinflammatory profiles during primary SIV infection in African green monkeys are associated with protection against AIDS. J Clin Invest. 2005; 115:1082-1091. [PubMed: 15761496]

108. Pandrea I, et al. Simian immunodeficiency virus SIVagm.sab infection of Caribbean African green monkeys: a new model for the study of SIV pathogenesis in natural hosts. J Virol. 2006; 80:4858-4867. [PubMed: 16641277]

109. Douek DC, Picker LJ, Koup RA. T cell dynamics in HIV-1 infection. Annu Rev Immunol. 2003; 21:265-304. [PubMed: 12524385]

110. Sachsenberg N, Perelson AS, Yerly S, Schockmel GA, Leduc D, Hirschel B, Perrin L. Turnover of CD4+ and CD8+ T lymphocytes in HIV-1 infection as measured by Ki-67 antigen. J Exp Med. 1998; 187:1295-1303. [PubMed: 9547340]

111. Mohri H, Bonhoeffer S, Simon M, Perelson AS, Ho DD. Rapid turnover of T lymphocytes in SIV-infected rhesus macaques. Science. 1998; 279:1223-1227. [PubMed: 9469816]

112. Combadere B, et al. CD4+Ki67+ lymphocytes in HIV-infected patients are effector T cells accumulated in the G1 phase of the cell cycle. Eur J Immunol. 2000; 30:3598-3603. [PubMed: 11169402]

113. Benecke A, Gale M Jr. Katze MG. Dynamics of innate immunity are key to chronic immune activation in AIDS. Curr Opin HIV AIDS. 2012; 7:79-85. [PubMed: 22156845]

114. Porichis F, Kaufmann DE. Role of PD-1 in HIV pathogenesis and as target for therapy. Curr HIV/ AIDS Rep. 2012; 9:81-90. [PubMed: 22198819]

115. Yue FY, Kovacs CM, Dimayuga RC, Gu XX, Parks P, Kaul R, Ostrowski MA. Preferential apoptosis of HIV-1-specific CD4+ T cells. J Immunol. 2005; 174:2196-2204. [PubMed: 15699152]

116. Xu H, Wang X, Morici LA, Pahar B, Veazey RS. Early divergent host responses in SHIVsf162P3 and SIVmac251 infected macaques correlate with control of viremia. PLoS One. 2011; 6:e17965. [PubMed: 21464951]

117. Keating SM, Jacobs ES, Norris PJ. Soluble mediators of inflammation in HIV and their implications for therapeutics and vaccine development. Cytokine Growth Factor Rev. 2012; 23:193-206. [PubMed: 22743035]

118. Brenchley JM, et al. Microbial translocation is a cause of systemic immune activation in chronic HIV infection. Nat Med. 2006; 12:1365-1371. [PubMed: 17115046]

119. Sandler NG, Douek DC. Microbial translocation in HIV infection: causes, consequences and treatment opportunities. Nat Rev Microbiol. 2012; 10:655-666. [PubMed: 22886237]

120. Schacker TW, et al. Lymphatic tissue fibrosis is associated with reduced numbers of naive CD4+ $\mathrm{T}$ cells in human immunodeficiency virus type 1 infection. Clin Vaccine Immunol. 2006; 13:556-560. [PubMed: 16682476]

121. Brenchley JM, et al. Differential Th17 CD4 T cell depletion in pathogenic and nonpathogenic lentiviral infections. Blood. 2008; 112:2826-2835. [PubMed: 18664624]

122. Estes JD, et al. Damaged intestinal epithelial integrity linked to microbial translocation in pathogenic simian immunodeficiency virus infections. PLoS Pathog. 2010; 6:e1001052. [PubMed: 20808901]

123. Sodora DL, Silvestri G. Immune activation and AIDS pathogenesis. AIDS. 2008; 22:439-446. [PubMed: 18301056] 
124. Wang X, et al. Simian immunodeficiency virus selectively infects proliferating CD4+ T cells in neonatal rhesus macaques. Blood. 2010; 116:4168-4174. [PubMed: 20716768]

125. Schacker TW, et al. Persistent abnormalities in lymphoid tissues of human immunodeficiency virus-infected patients successfully treated with highly active antiretroviral therapy. J Infect Dis. 2002; 186:1092-1097. [PubMed: 12355359]

126. Estes J, et al. Collagen deposition limits immune reconstitution in the gut. J Infect Dis. 2008; 198:456-464. [PubMed: 18598193]

127. Nazli A, et al. Exposure to HIV-1 directly impairs mucosal epithelial barrier integrity allowing microbial translocation. PLoS Pathog. 2010; 6:e1000852. [PubMed: 20386714]

128. Douek DC, et al. HIV preferentially infects HIV-specific CD4+ T cells. Nature. 2002; 417:95-98. [PubMed: 11986671]

129. Veazey RS. Mucosal immunopathogenesis of HIV infection: implications for vaccine development. Future HIV Therapy. 2007; 1:103-112.

130. Handley SA, et al. Pathogenic simian immunodeficiency virus infection is associated with expansion of the enteric virome. Cell. 2012; 151:253-266. [PubMed: 23063120]

131. Veazey RS, Lackner AA. Getting to the guts of HIV pathogenesis. J Exp Med. 2004; 200:697700. [PubMed: 15381725]

132. Veazey RS, et al. Identifying the target cell in primary simian immunodeficiency virus (SIV) infection: highly activated memory CD4(+) T cells are rapidly eliminated in early SIV infection in vivo. J Virol. 2000; 74:57-64. [PubMed: 10590091]

133. Mehandru S, et al. Primary HIV-1 infection is associated with preferential depletion of CD4+ T lymphocytes from effector sites in the gastrointestinal tract. J Exp Med. 2004; 200:761-770. [PubMed: 15365095]

134. Mosmann TR, Kobie JJ, Lee FE, Quataert SA. T helper cytokine patterns: defined subsets, random expression, and external modulation. Immunol Res. 2009; 45:173-184. [PubMed: 19198763]

135. Mosmann TR, Cherwinski H, Bond MW, Giedlin MA, Coffman RL. Two types of murine helper T cell clone. I. Definition according to profiles of lymphokine activities and secreted proteins. J Immunol. 1986; 136:2348-2357. [PubMed: 2419430]

136. Walker JA, Barlow JL, McKenzie AN. Innate lymphoid cells - how did we miss them? Nat Rev Immunol. 2013; 13:75-87. [PubMed: 23292121]

137. McMichael AJ, Borrow P, Tomaras GD, Goonetilleke N, Haynes BF. The immune response during acute HIV-1 infection: clues for vaccine development. Nat Rev Immunol. 2010; 10:1123. [PubMed: 20010788]

138. Klein SA, et al. Demonstration of the Th1 and Th2 cytokine shift during the course of HIV-1 infection using cytoplasmic cytokine detection on single cell level by flow cytometry. AIDS. 1997; 11:1111-1118. [PubMed: 9233457]

139. Bostik P, Watkins M, Villinger F, Ansari AA. Genetic analysis of cytokine promoters in nonhuman primates: implications for Th1/Th2 profile characteristics and SIV disease pathogenesis. Clin Dev Immunol. 2004; 11:35-44. [PubMed: 15154610]

140. Stylianou E, Aukrust P, Kvale D, Muller F, Froland SS. IL-10 in HIV infection: increasing serum IL-10 levels with disease progression--down-regulatory effect of potent anti-retroviral therapy. Clin Exp Immunol. 1999; 116:115-120. [PubMed: 10209514]

141. Benveniste O, et al. Comparative interleukin (IL)-2/interferon (IFN)-g and IL-4/IL-10 responses during acute infection of macaques inoculated with attenuated nef-truncated or pathogenic SIVmac251 virus. Proc Natl Acad Sci USA. 1996; 93:3658-3663. [PubMed: 8622992]

142. Li Y, Ling W, Xu H, Wang M, Wu C. The activation and dynamics of cytokine expression by CD4+ T cells and AIDS progression in HIV-1-infected Chinese individuals. Microb Pathog. 2012; 53:189-197. [PubMed: 22892467]

143. Bahbouhi B, Landay A, Al-Harthi L. Dynamics of cytokine expression in HIV productively infected primary CD4+ T cells. Blood. 2004; 103:4581-4587. [PubMed: 14764521]

144. Korn T, Bettelli E, Oukka M, Kuchroo VK. IL-17 and Th17 Cells. Annu Rev Immunol. 2009; 27:485-517. [PubMed: 19132915] 
145. Ivanov, et al. Induction of intestinal Th17 cells by segmented filamentous bacteria. Cell. 2009; 139:485-498. [PubMed: 19836068]

146. Zaph C, et al. Commensal-dependent expression of IL-25 regulates the IL-23-IL-17 axis in the intestine. J Exp Med. 2008; 205:2191-2198. [PubMed: 18762568]

147. Mayuzumi H, Inagaki-Ohara K, Uyttenhove C, Okamoto Y, Matsuzaki G. Interleukin-17A is required to suppress invasion of Salmonella enterica serovar Typhimurium to enteric mucosa. Immunology. 2010; 131:377-385. [PubMed: 20575990]

148. Santaolalla R, Abreu MT. Innate immunity in the small intestine. Curr Opin Gastroenterol. 2012; 28:124-129. [PubMed: 22241076]

149. Favre D, et al. Critical loss of the balance between Th17 and T regulatory cell populations in pathogenic SIV infection. PLoS Pathog. 2009; 5:e1000295. [PubMed: 19214220]

150. Cecchinato V, Franchini G. Th17 cells in pathogenic simian immunodeficiency virus infection of macaques. Curr Opin HIV AIDS. 2010; 5:141-145. [PubMed: 20543591]

151. Klatt NR, Brenchley JM. Th17 cell dynamics in HIV infection. Curr Opin HIV AIDS. 2010; 5:135-140. [PubMed: 20543590]

152. Cecchinato V, et al. Altered balance between Th17 and Th1 cells at mucosal sites predicts AIDS progression in simian immunodeficiency virus-infected macaques. Mucosal Immunol. 2008; 1:279-288. [PubMed: 19079189]

153. Xu H, Wang X, Liu DX, Moroney-Rasmussen T, Lackner AA, Veazey RS. IL-17-producing innate lymphoid cells are restricted to mucosal tissues and are depleted in SIV-infected macaques. Mucosal Immunol. 2012; 5:658-669. [PubMed: 22669579]

154. Hartigan-O' connor DJ, Hirao LA, McCune JM, Dandekar S. Th17 cells and regulatory T cells in elite control over HIV and SIV. Curr Opin HIV AIDS. 2011; 6:221-227. [PubMed: 21399494]

155. Brandt L, et al. Low level of regulatory T-cells and maintenance of balance between regulatory $\mathrm{T}$ cells and TH17 cells in HIV-1-infected elite controllers. J Acquir Immune Defic Syndr. 2011; 57:101-108. [PubMed: 21407087]

156. Ciccone EJ, et al. CD4+ T cells, including Th17 and cycling subsets, are intact in the gut mucosa of HIV-1 infected long-term non-progressors. J Virol. 2011; 85:5880-5888. [PubMed: 21471231]

157. Campbell DJ, Koch MA. Phenotypical and functional specialization of FOXP3+ regulatory T cells. Nat Rev Immunol. 2011; 11:119-130. [PubMed: 21267013]

158. Schulze Zur Wiesch J, et al. Comprehensive analysis of frequency and phenotype of T regulatory cells in HIV infection: CD39 expression of FoxP3+ T regulatory cells correlates with progressive disease. J Virol. 2011; 85:1287-1297. [PubMed: 21047964]

159. Boasso A, et al. Regulatory T-cell markers, indoleamine 2,3-dioxygenase, and virus levels in spleen and gut during progressive simian immunodeficiency virus infection. J Virol. 2007; 81:11593-11603. [PubMed: 17715231]

160. Aandahl EM, Michaelsson J, Moretto WJ, Hecht FM, Nixon DF. Human CD4+ CD25+ regulatory $\mathrm{T}$ cells control $\mathrm{T}$-cell responses to human immunodeficiency virus and cytomegalovirus antigens. J Virol. 2004; 78:2454-2459. [PubMed: 14963140]

161. Janssen EM, Lemmens EE, Wolfe T, Christen U, von Herrath MG, Schoenberger SP. CD4+ T cells are required for secondary expansion and memory in CD8+ T lymphocytes. Nature. 2003; 421:852-856. [PubMed: 12594515]

162. Sun JC, Bevan MJ. Defective CD8 T cell memory following acute infection without CD4 T cell help. Science. 2003; 300:339-342. [PubMed: 12690202]

163. Shedlock DJ, Shen H. Requirement for CD4 T cell help in generating functional CD8 T cell memory. Science. 2003; 300:337-339. [PubMed: 12690201]

164. MacLennan IC. Somatic mutation. From the dark zone to the light. Curr Biol. 1994; 4:70-72. [PubMed: 7922318]

165. Liu YJ, Grouard G, de Bouteiller O, Banchereau J. Follicular dendritic cells and germinal centers. Int Rev Cytol. 1996; 166:139-179. [PubMed: 8881775]

166. King C, Sprent J. Emerging cellular networks for regulation of T follicular helper cells. Trends Immunol. 2012; 33:59-65. [PubMed: 22209178] 
167. Crotty S. Follicular helper CD4 T cells (TFH). Annu Rev Immunol. 2011; 29:621-663. [PubMed: 21314428]

168. Yu D, Vinuesa CG. The elusive identity of T follicular helper cells. Trends Immunol. 2010; 31:377-383. [PubMed: 20810318]

169. Johnston RJ, et al. Bcl6 and Blimp-1 are reciprocal and antagonistic regulators of T follicular helper cell differentiation. Science. 2009; 325:1006-1010. [PubMed: 19608860]

170. Lindqvist M, et al. Expansion of HIV-specific T follicular helper cells in chronic HIV infection. J Clin Invest. 2012; 122:3271-3280. [PubMed: 22922259]

171. Petrovas C, et al. CD4 T follicular helper cell dynamics during SIV infection. J Clin Invest. 2012; 122:3281-3294. [PubMed: 22922258]

172. Hong JJ, Amancha PK, Rogers K, Ansari AA, Villinger F. Spatial alterations between CD4(+) T follicular helper, $\mathrm{B}$, and CD8(+) T cells during simian immunodeficiency virus infection: T/B cell homeostasis, activation, and potential mechanism for viral escape. J Immunol. 2012; 188:3247-3256. [PubMed: 22387550]

173. Perreau M, Savoye AL, De Crignis E, Corpataux JM, Cubas R, Haddad EK, De Leval L, Graziosi C, Pantaleo G. Follicular helper T cells serve as the major CD4 T cell compartment for HIV-1 infection, replication, and production. J Exp Med. 2013; 210:143-156. [PubMed: 23254284]

174. Borrow P, Lewicki H, Hahn BH, Shaw GM, Oldstone MB. Virus-specific CD8+ cytotoxic Tlymphocyte activity associated with control of viremia in primary human immunodeficiency virus type 1 infection. J Virol. 1994; 68:6103-6110. [PubMed: 8057491]

175. Koup RA, et al. Temporal association of cellular immune responses with the initial control of viremia in primary human immunodeficiency virus type 1 syndrome. J Virol. 1994; 68:4650 4655. [PubMed: 8207839]

176. Wilson JD, et al. Direct visualization of HIV-1-specific cytotoxic T lymphocytes during primary infection. AIDS. 2000; 14:225-233. [PubMed: 10716497]

177. Reynolds MR, et al. CD8+ T-lymphocyte response to major immunodominant epitopes after vaginal exposure to simian immunodeficiency virus: too late and too little. J Virol. 2005; 79:9228-9235. [PubMed: 15994817]

178. Schmitz JE, et al. Control of viremia in simian immunodeficiency virus infection by CD8+ lymphocytes. Science. 1999; 283:857-860. [PubMed: 9933172]

179. Klatt NR, et al. CD8+ lymphocytes control viral replication in SIVmac239-infected rhesus macaques without decreasing the lifespan of productively infected cells. PLoS Pathog. 2010; 6:e1000747. [PubMed: 20126441]

180. Reynolds MR, et al. Macaques vaccinated with live-attenuated SIV control replication of heterologous virus. J Exp Med. 2008; 205:2537-2550. [PubMed: 18838548]

181. Veazey RS, et al. Emergence and kinetics of simian immunodeficiency virus-specific CD8(+) T cells in the intestines of macaques during primary infection. J Virol. 2001; 75:10515-10519. [PubMed: 11581423]

182. Brennan TP, Woods JO, Sedaghat AR, Siliciano JD, Siliciano RF, Wilke CO. Analysis of human immunodeficiency virus type 1 viremia and provirus in resting CD4+ T cells reveals a novel source of residual viremia in patients on antiretroviral therapy. J Virol. 2009; 83:8470-8481. [PubMed: 19535437]

183. Veazey RS, et al. Dynamics of Simian immunodeficiency virus-specific cytotoxic T-cell responses in tissues. J Med Primatol. 2003; 32:194-200. [PubMed: 14498979]

184. Belyakov IM, Ahlers JD, Nabel GJ, Moss B, Berzofsky JA. Generation of functionally active HIV-1 specific CD8+ CTL in intestinal mucosa following mucosal, systemic or mixed primeboost immunization. Virology. 2008; 381:106-115. [PubMed: 18793787]

185. Kaul R, et al. Quantitative ex vivo analysis of functional virus-specific CD8 T lymphocytes in the blood and genital tract of HIV-infected women. AIDS. 2003; 17:1139-1144. [PubMed: 12819514]

186. Kaul R, et al. HIV-1-specific mucosal CD8+ lymphocyte responses in the cervix of HIV-1resistant prostitutes in Nairobi. J Immunol. 2000; 164:1602-1611. [PubMed: 10640781] 
187. Mendiratta S, Vajpayee M, Mojumdar K, Chauhan NK, Sreenivas V. Polyfunctional analysis of Gag and Nef specific CD8+ T-cell responses in HIV-1 infected Indian individuals. Vaccine. 2011; 29:1150-1158. [PubMed: 21172377]

188. Goonetilleke N, et al. The first $\mathrm{T}$ cell response to transmitted/founder virus contributes to the control of acute viremia in HIV-1 infection. J Exp Med. 2009; 206:1253-1272. [PubMed: 19487423]

189. Turnbull EL, et al. Kinetics of expansion of epitope-specific $\mathrm{T}$ cell responses during primary HIV-1 infection. J Immunol. 2009; 182:7131-7145. [PubMed: 19454710]

190. Allen TM, et al. Tat-specific cytotoxic T lymphocytes select for SIV escape variants during resolution of primary viremia. Nature. 2000; 407:386-390. [PubMed: 11014195]

191. Picker LJ. Immunopathogenesis of acute AIDS virus infection. Curr Opin Immunol. 2006; 18:399-405. [PubMed: 16753288]

192. Kaech SM, Wherry EJ. Heterogeneity and cell-fate decisions in effector and memory CD8+ T cell differentiation during viral infection. Immunity. 2007; 27:393-405. [PubMed: 17892848]

193. Williams MA, Bevan MJ. Effector and memory CTL differentiation. Annu Rev Immunol. 2007; 25:171-192. [PubMed: 17129182]

194. Arens R, Schoenberger SP. Plasticity in programming of effector and memory CD8 T-cell formation. Immunol Rev. 2010; 235:190-205. [PubMed: 20536564]

195. Masopust D, Kaech SM, Wherry EJ, Ahmed R. The role of programming in memory T-cell development. Curr Opin Immunol. 2004; 16:217-225. [PubMed: 15023416]

196. Wherry EJ, et al. Molecular signature of CD8+ T cell exhaustion during chronic viral infection. Immunity. 2007; 27:670-684. [PubMed: 17950003]

197. Fuller MJ, Zajac AJ. Ablation of CD8 and CD4 T cell responses by high viral loads. J Immunol. 2003; 170:477-486. [PubMed: 12496434]

198. Shin H, Blackburn SD, Intlekofer AM, Kao C, Angelosanto JM, Reiner SL, Wherry EJ. A role for the transcriptional repressor Blimp-1 in CD8(+) T cell exhaustion during chronic viral infection. Immunity. 2009; 31:309-320. [PubMed: 19664943]

199. Blackburn SD, et al. Coregulation of CD8+ T cell exhaustion by multiple inhibitory receptors during chronic viral infection. Nat Immunol. 2009; 10:29-37. [PubMed: 19043418]

200. Blackburn SD, Crawford A, Shin H, Polley A, Freeman GJ, Wherry EJ. Tissue-specific differences in PD-1 and PD-L1 expression during chronic viral infection: implications for CD8 T-cell exhaustion. J Virol. 2010; 84:2078-2089. [PubMed: 19955307]

201. Ortiz AM, et al. Depletion of CD4(+) T cells abrogates post-peak decline of viremia in SIVinfected rhesus macaques. J Clin Invest. 2011; 121:4433-4445. [PubMed: 22005304]

202. Jones NG, DeCamp A, Gilbert P, Peterson ML, Gurwith M, Cao H. AIDSVAX immunization induces HIV-specific CD8+ T-cell responses in high-risk, HIV-negative volunteers who subsequently acquire HIV infection. Vaccine. 2009; 27:1136-1140. [PubMed: 19071176]

203. Crellin NK, Trifari S, Kaplan CD, Cupedo T, Spits H. Human NKp44+IL-22+ cells and LTi-like cells constitute a stable RORC+ lineage distinct from conventional natural killer cells. J Exp Med. 2010; 207:281-290. [PubMed: 20142432]

204. Satoh-Takayama N, et al. IL-7 and IL-15 independently program the differentiation of intestinal CD3-NKp46+ cell subsets from Id2-dependent precursors. J Exp Med. 2010; 207:273-280. [PubMed: 20142427]

205. Kanamori Y, et al. Identification of novel lymphoid tissues in murine intestinal mucosa where clusters of c-kit+ IL-7R+ Thy1+ lympho-hemopoietic progenitors develop. J Exp Med. 1996; 184:1449-1459. [PubMed: 8879216]

206. Eberl G, Sawa S. Opening the crypt: current facts and hypotheses on the function of cryptopatches. Trends Immunol. 2010; 31:50-55. [PubMed: 20015688]

207. Spits H, Di Santo JP. The expanding family of innate lymphoid cells: regulators and effectors of immunity and tissue remodeling. Nat Immunol. 2011; 12:21-27. [PubMed: 21113163]

208. Tsuji NM, Kosaka A. Oral tolerance: intestinal homeostasis and antigen-specific regulatory $\mathrm{T}$ cells. Trends Immunol. 2008; 29:532-540. [PubMed: 18835746]

209. Withers DR. Lymphoid tissue inducer cells. Curr Biol. 2011; 21:R381-382. [PubMed: 21601793] 
210. Lane PJ, Kim MY, Gaspal FM, McConnell FM. CD4+CD3- cells regulate the organization of lymphoid tissue and T-cell memory for antibody responses. Int J Hematol. 2006; 83:12-16. [PubMed: 16443546]

211. Sawa S, et al. RORgammat+ innate lymphoid cells regulate intestinal homeostasis by integrating negative signals from the symbiotic microbiota. Nat Immunol. 2011; 12:320-326. [PubMed: 21336274]

212. Reeves RK, et al. Gut inflammation and indoleamine deoxygenase inhibit IL-17 production and promote cytotoxic potential in NKp44+ mucosal NK cells during SIV infection. Blood. 2011; 118:3321-3330. [PubMed: 21791421]

213. Carrington M, Alter G. Innate Immune Control of HIV. Cold Spring Harb Perspect Med. 2012; 2:a007070. [PubMed: 22762020]

214. Martin MP, et al. Epistatic interaction between KIR3DS1 and HLA-B delays the progression to AIDS. Nat Genet. 2002; 31:429-434. [PubMed: 12134147]

215. Cohen GB, et al. The selective downregulation of class I major histocompatibility complex proteins by HIV-1 protects HIV-infected cells from NK cells. Immunity. 1999; 10:661-671. [PubMed: 10403641]

216. Shacklett BL. Understanding the "lucky few": the conundrum of HIV-exposed, seronegative individuals. Curr HIV/AIDS Rep. 2006; 3:26-31. [PubMed: 16522256]

217. Embretson J, Zupancic M, Ribas JL, Burke A, Racz P, Tenner-Racz K, Haase AT. Massive cohert infection of helper T lymphocytes and macrophages by HIV during the incubation period of AIDS. Nature. 1993; 362:359-362. [PubMed: 8096068]

218. Pantaleo G, et al. HIV infection is active and progressive in lymphoid tissue during the clinically latent stage of disease. Nature. 1993; 362:355-362. [PubMed: 8455722]

219. Poles MA, et al. Lack of decay of HIV-1 in gut-associated lymphoid tissue reservoirs in maximally suppressed individuals. J Acquir Immune Defic Syndr. 2006; 43:65-68. [PubMed: 16936559]

220. Manheimer-Lory AJ, Zandman-Goddard G, Davidson A, Aranow C, Diamond B. Lupus-specific antibodies reveal an altered pattern of somatic mutation. J Clin Invest. 1997; 100:2538-2546. [PubMed: 9366568]

221. Zeng M, et al. Cumulative mechanisms of lymphoid tissue fibrosis and T cell depletion in HIV-1 and SIV infections. J Clin Invest. 2011; 121:998-1008. [PubMed: 21393864]

222. Pantaleo G, Graziosi C, Fauci AS. The immunopathogenesis of human immunodeficiency virus infection. N Engl J Med. 1993; 328:327-335. [PubMed: 8093551]

223. Zeng M, Haase AT, Schacker TW. Lymphoid tissue structure and HIV-1 infection: life or death for T cells. Trends Immunol. 2012; 33:306-314. [PubMed: 22613276]

224. Levesque MC, et al. Polyclonal B cell differentiation and loss of gastrointestinal tract germinal centers in the earliest stages of HIV-1 infection. PLoS Med. 2009; 6:e1000107. [PubMed: 19582166]

225. Dykhuizen M, Mitchen JL, Montefiori DC, Thomson J, Acker L, Lardy H, Pauza CD. Determinants of disease in the simian immunodeficiency virus-infected rhesus macaque: characterizing animals with low antibody responses and rapid progression. J Gen Virol. 1998; 79:2461-2467. [PubMed: 9780052]

226. Imagawa DT, et al. Human immunodeficiency virus type 1 infection in homosexual men who remain seronegative for prolonged periods. N Engl J Med. 1989; 320:1458-1462. [PubMed: 2716797]

227. Michael NL, et al. Rapid disease progression without seroconversion following primary human immunodeficiency virus type 1 infection--evidence for highly susceptible human hosts. J Infect Dis. 1997; 175:1352-1359. [PubMed: 9180174]

228. Tenner-Racz K, Racz P. Follicular dendritic cells initiate and maintain infection of the germinal centers by human immunodeficiency virus. Curr Top Microbiol Immunol. 1995; 201:141-159. [PubMed: 7587348]

229. Langford TD, et al. Central importance of immunoglobulin A in host defense against Giardia spp. Infect Immun. 2002; 70:11-18. [PubMed: 11748158] 
230. Hapfelmeier S, et al. Reversible microbial colonization of germ-free mice reveals the dynamics of IgA immune responses. Science. 2010; 328:1705-1709. [PubMed: 20576892]

231. Tsuji M, et al. Preferential generation of follicular B helper T cells from Foxp3+ T cells in gut Peyer's patches. Science. 2009; 323:1488-1492. [PubMed: 19286559]

232. Stavnezer J, Kang J. The surprising discovery that TGF beta specifically induces the IgA class switch. J Immunol. 2009; 182:5-7. [PubMed: 19109126]

233. Tsuji M, et al. Requirement for lymphoid tissue-inducer cells in isolated follicle formation and $\mathrm{T}$ cell-independent immunoglobulin A generation in the gut. Immunity. 2008; 29:261-271. [PubMed: 18656387]

234. Wei X, et al. Antibody neutralization and escape by HIV-1. Nature. 2003; 422:307-312. [PubMed: 12646921]

235. Richman DD, Wrin T, Little SJ, Petropoulos CJ. Rapid evolution of the neutralizing antibody response to HIV type 1 infection. Proc Natl Acad Sci USA. 2003; 100:4144-4149. [PubMed: 12644702]

236. Zhang ZQ, et al. Early depletion of proliferating B cells of germinal center in rapidly progressive simian immunodeficiency virus infection. Virology. 2007; 361:455-464. [PubMed: 17223151]

237. Alam SM, et al. Human immunodeficiency virus type $1 \mathrm{gp} 41$ antibodies that mask membrane proximal region epitopes: antibody binding kinetics, induction, and potential for regulation in acute infection. J Virol. 2008; 82:115-125. [PubMed: 17942537]

238. Mestecky J, Raska M, Novak J, Alexander RC, Moldoveanu Z. Antibody-mediated protection and the mucosal immune system of the genital tract: relevance to vaccine design. J Reprod Immunol. 2010; 85:81-85. [PubMed: 20236708]

239. Russell MW, Mestecky J. Humoral immune responses to microbial infections in the genital tract. Microbes Infect. 2002; 4:667-677. [PubMed: 12048036]

240. Moldoveanu Z, Huang WQ, Kulhavy R, Pate MS, Mestecky J. Human male genital tract secretions: both mucosal and systemic immune compartments contribute to the humoral immunity. J Immunol. 2005; 175:4127-4136. [PubMed: 16148163]

241. Miller CJ, et al. Genital secretory immune response to chronic simian immunodeficiency virus (SIV) infection: a comparison between intravenously and genitally inoculated rhesus macaques. Clin Exp Immunol. 1992; 88:520-526. [PubMed: 1606737]

242. Parren PW, et al. Antibody protects macaques against vaginal challenge with a pathogenic R5 simian/human immunodeficiency virus at serum levels giving complete neutralization in vitro. $\mathrm{J}$ Virol. 2001; 75:8340-8347. [PubMed: 11483779]

243. Baba TW, et al. Human neutralizing monoclonal antibodies of the IgG1 subtype protect against mucosal simian-human immunodeficiency virus infection. Nat Med. 2000; 6:200-206. [PubMed: 10655110]

244. Flynn NM, Forthal DN, Harro CD, Judson FN, Mayer KH, Para MF. Placebo-controlled phase 3 trial of a recombinant glycoprotein 120 vaccine to prevent HIV-1 infection. J Infect Dis. 2005; 191:654-665. [PubMed: 15688278]

245. McCarthy M. HIV vaccine fails in phase 3 trial. Lancet. 2003; 361:755-756. [PubMed: 12620743]

246. Gray RH, Tobian A, Kigozi G, Wawer MJ, Serwadda D. Commentary: male circumcision for prevention of heterosexual acquisition of HIV in men: perspective from a trial team. Int $\mathrm{J}$ Epidemiol. 2010; 39:970-971. [PubMed: 20624821]

247. Nicholson O, et al. Safety and immunogenicity of the MRKAd5 gag HIV type 1 vaccine in a worldwide phase 1 study of healthy adults. AIDS Res Hum Retroviruses. 2011; 27:557-567.

248. Staprans SI, et al. Enhanced SIV replication and accelerated progression to AIDS in macaques primed to mount a CD4 T cell response to the SIV envelope protein. Proc Natl Acad Sci USA. 2004; 101:13026-13031. [PubMed: 15326293]

249. McElrath MJ, Haynes BF. Induction of immunity to human immunodeficiency virus type-1 by vaccination. Immunity. 2010; 33:542-554. [PubMed: 21029964]

250. Bonsignori M, et al. Antibody-dependent cellular cytotoxicity-mediating antibodies from an HIV-1 vaccine efficacy trial target multiple epitopes and preferentially use the VH1 gene family. J Virol. 2012; 86:11521-11532. [PubMed: 22896626] 
251. Hansen SG, et al. Profound early control of highly pathogenic SIV by an effector memory T-cell vaccine. Nature. 2011; 473:523-527. [PubMed: 21562493]

252. Johnson RP, Desrosiers RC. Protective immunity induced by live attenuated simian immunodeficiency virus. Curr Opin Immunol. 1998; 10:436-443. [PubMed: 9722920]

253. Daniel MD, Kirchhoff F, Czajak SC, Sehgal PK, Desrosiers RC. Protective effects of a live attenuated SIV vaccine with a deletion in the nef gene. Science. 1992; 258:1938-1941. [PubMed: 1470917]

254. Alpert MD, et al. ADCC develops over time during persistent infection with live-attenuated SIV and is associated with complete protection against SIV(mac)251 challenge. PLoS Pathog. 2012; 8:e1002890. [PubMed: 22927823]

255. Fukazawa Y, et al. Lymph node T cell responses predict the efficacy of live attenuated SIV vaccines. Nat Med. 2012; 18:1673-1681. [PubMed: 22961108]

256. Patterson LJ, et al. Replicating adenovirus-simian immunodeficiency virus (SIV) vectors efficiently prime SIV-specific systemic and mucosal immune responses by targeting myeloid dendritic cells and persisting in rectal macrophages, regardless of immunization route. Clin Vaccine Immunol. 2012; 19:629-637. [PubMed: 22441384]

257. Vargas-Inchaustegui DA, Xiao P, Tuero I, Patterson LJ, Robert-Guroff M. NK and CD4+ T cell cooperative immune responses correlate with control of disease in a macaque simian immunodeficiency virus infection model. J Immunol. 2012; 189:1878-1885. [PubMed: 22798665]

258. Xiao P, et al. Replicating adenovirus-simian immunodeficiency virus (SIV) recombinant priming and envelope protein boosting elicits localized, mucosal $\operatorname{IgA}$ immunity in rhesus macaques correlated with delayed acquisition following a repeated low-dose rectal SIV(mac251) challenge. J Virol. 2012; 86:4644-4657. [PubMed: 22345466]

259. Letvin NL, et al. Immune and Genetic Correlates of Vaccine Protection Against Mucosal Infection by SIV in Monkeys. Sci Transl Med. 2011; 3:81ra36.

260. Flatz L, et al. Gene-based vaccination with a mismatched envelope protects against simian immunodeficiency virus infection in nonhuman primates. J Virol. 2012; 86:7760-7770. [PubMed: 22593152]

261. Banks ND, Kinsey N, Clements J, Hildreth JE. Sustained antibody-dependent cell-mediated cytotoxicity (ADCC) in SIV-infected macaques correlates with delayed progression to AIDS. AIDS Res Hum Retroviruses. 2002; 18:1197-1205. [PubMed: 12487826]

262. Gomez-Roman VR, et al. Vaccine-elicited antibodies mediate antibody-dependent cellular cytotoxicity correlated with significantly reduced acute viremia in rhesus macaques challenged with SIVmac251. J Immunol. 2005; 174:2185-2189. [PubMed: 15699150]

263. Florese RH, et al. Contribution of nonneutralizing vaccine-elicited antibody activities to improved protective efficacy in rhesus macaques immunized with Tat/Env compared with multigenic vaccines. J Immunol. 2009; 182:3718-3727. [PubMed: 19265150]

264. Overbaugh J, Morris L. The Antibody Response against HIV-1. Cold Spring Harb Perspect Med. 2012; 2:a007039. [PubMed: 22315717]

265. Sant AJ, McMichael A. Revealing the role of CD4(+) T cells in viral immunity. J Exp Med. 2012; 209:1391-1395. [PubMed: 22851641]

266. Soghoian DZ, et al. HIV-specific cytolytic CD4 T cell responses during acute HIV infection predict disease outcome. Sci Transl Med. 2012; 4:123ra125.

267. Soghoian DZ, Streeck H. Cytolytic CD4(+) T cells in viral immunity. Expert Rev Vaccines. 2010; 9:1453-1463. [PubMed: 21105780]

268. Ranasinghe S, et al. HIV-specific CD4 T cell responses to different viral proteins have discordant associations with viral load and clinical outcome. J Virol. 2012; 86:277-283. [PubMed: 22031937]

269. Zhou Y, et al. Dominance of the CD4(+) T helper cell response during acute resolving hepatitis A virus infection. J Exp Med. 2012; 209:1481-1492. [PubMed: 22753925]

270. Klatt NR, Silvestri G. CD4+ T cells and HIV: A paradoxical Pas de Deux. Sci Transl Med. 2012; 4:123ps 124 . 
271. Gloster SE, et al. Association of strong virus-specific CD4 T cell responses with efficient natural control of primary HIV-1 infection. AIDS. 2004; 18:749-755. [PubMed: 15075509]

272. Zheng N, Fujiwara M, Ueno T, Oka S, Takiguchi M. Strong ability of Nef-specific CD4+ cytotoxic T cells to suppress human immunodeficiency virus type 1 (HIV-1) replication in HIV-1-infected CD4+ T cells and macrophages. J Virol. 2009; 83:7668-7677. [PubMed: 19457989] 


\section{Vagina HLADR CD1a CD3}

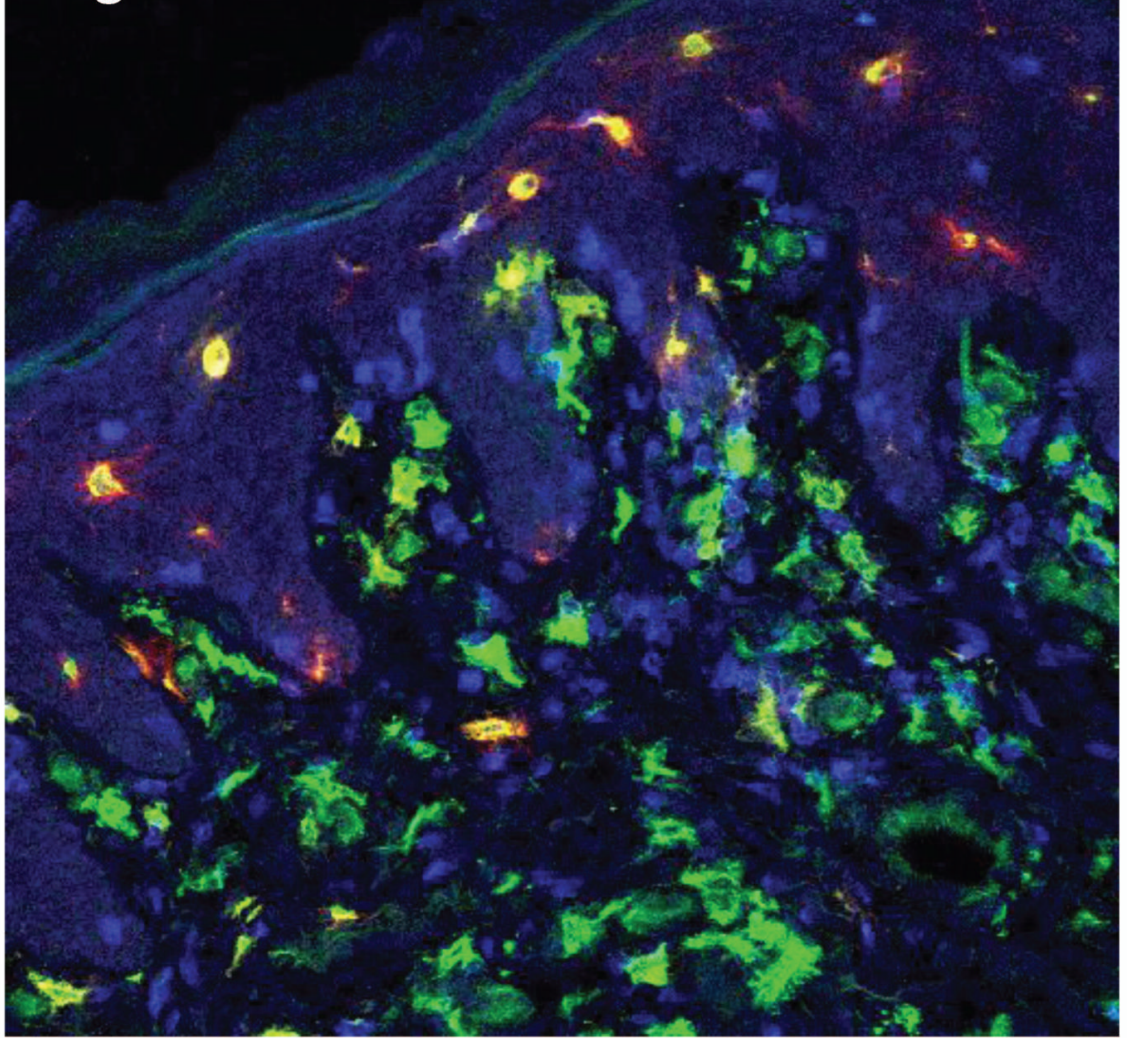

Fig. 1. Langerhans cells in the vaginal epithelium distinguished by co-expression of HLA-DR and CD1a (LC appear yellow - see arrows)

Other DCs are evident in the deeper lamina propria as HLA-DR ${ }^{+}$(green), yet HLA-DR alone is not specific for DCs. 


\section{Intestine (GALT)}

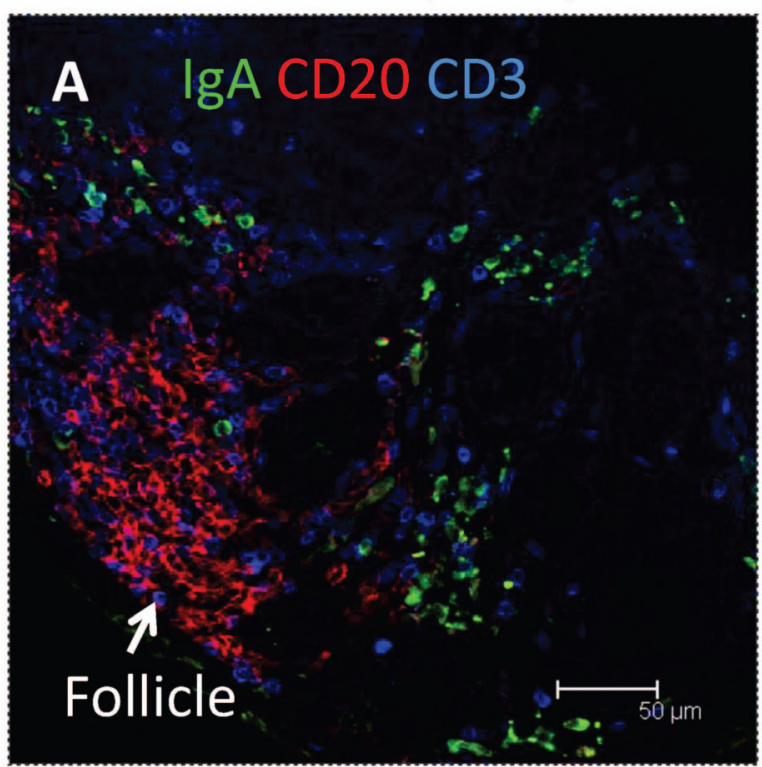

\section{Lymph node}

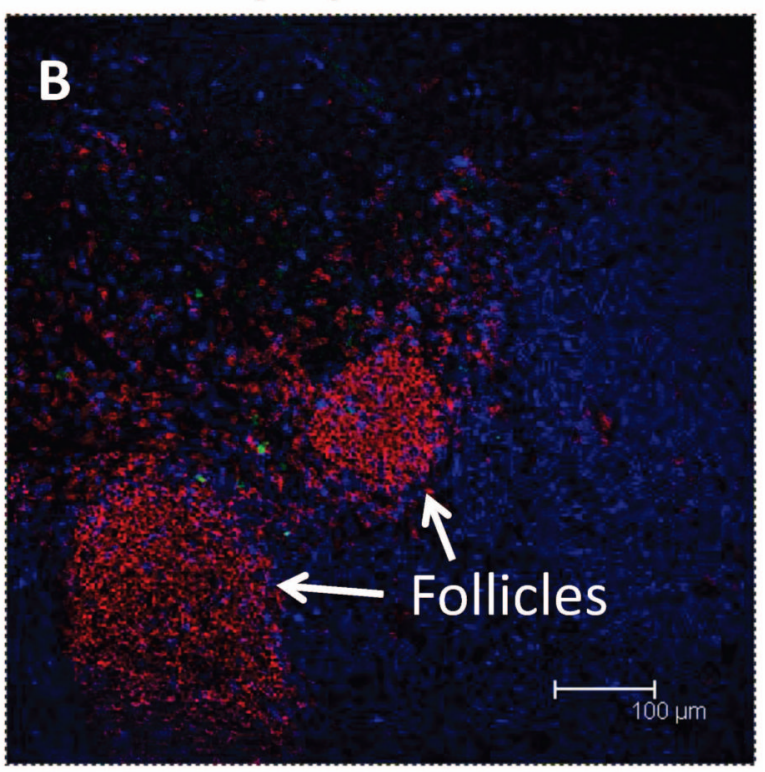

Fig. 2. Lymphoid follicles within organized lymphoid tissue

Follicles are within the intestine (A) and lymph node (B) showing distribution of B cells (red) and T-cell zones (blue). Note IgA (green) is readily detected in cells in the intestinal lamina propria but not detectable in peripheral lymph nodes. 
Intestine

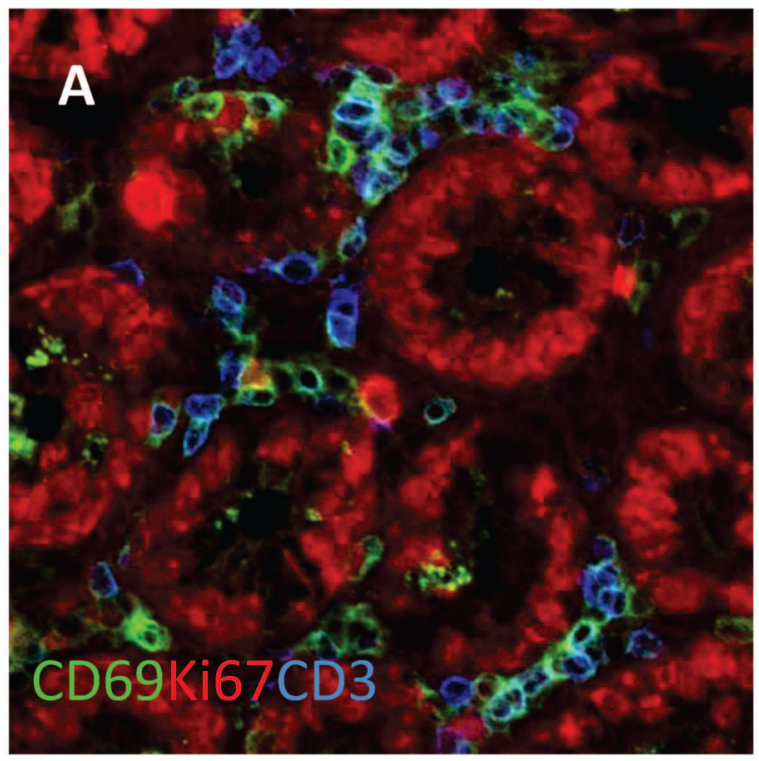

Lymph node

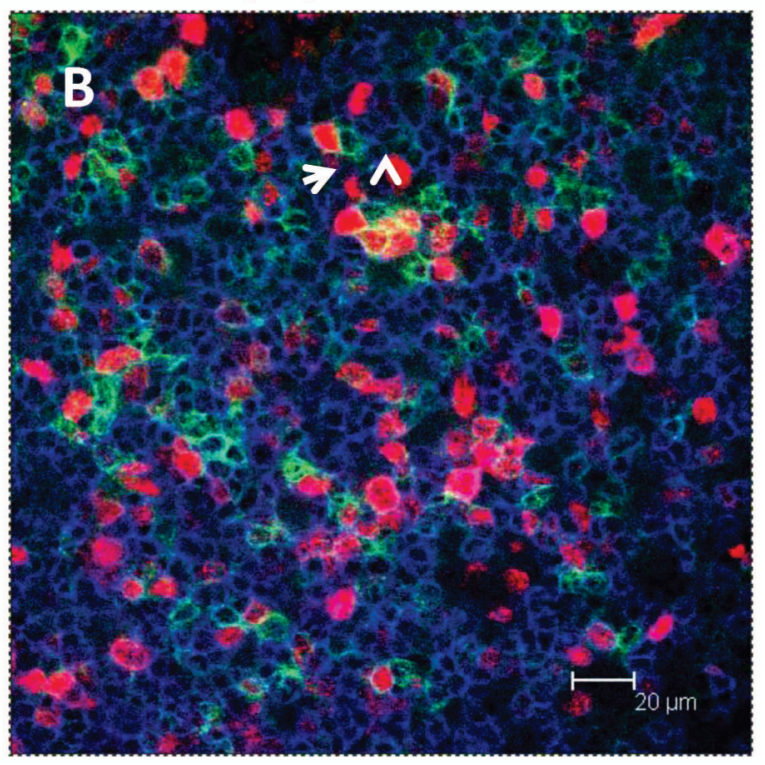

Fig. 3. T-cell proliferation $\left(\mathrm{Ki}-67^{+}\right.$, red) and activation $\left(\mathrm{CD69}^{+}\right.$, green) in the intestinal lamina propria $(A)$ and lymph node $(B)$ of a normal macaque

Abundant activated (CD69+; green) $\mathrm{KI}-67^{+} \mathrm{T}$ cells are constitutively present in intestinal tissues, but activated cells are rare in normal lymph nodes. Note intestinal crypt epithelial cells are also highly $\mathrm{Ki}-67^{+}$due to intrinsic rapid rate of turnover. 


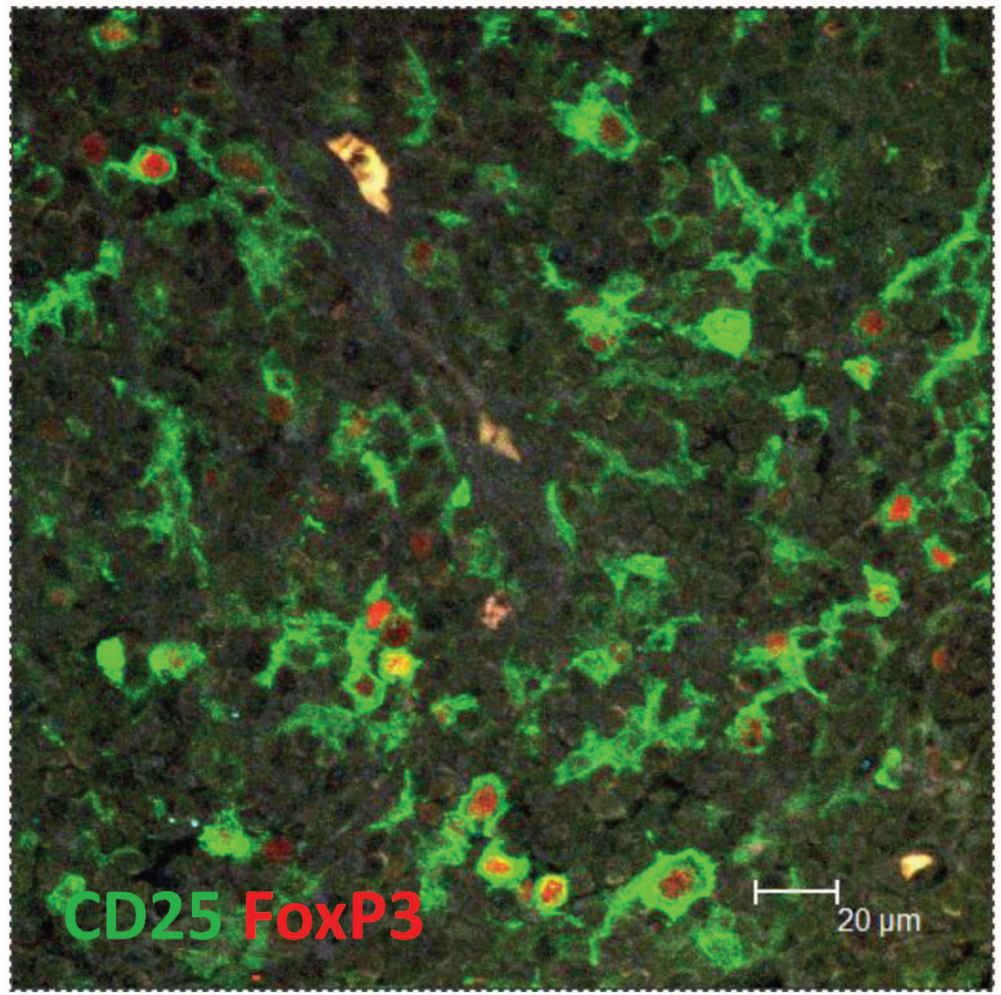

Fig. 4. T-regulatory (Treg) cells in the intestinal lamina propria of a normal macaque distinguished by intracellular FoxP3 (red nuclei) and surface CD25 (green) expression 

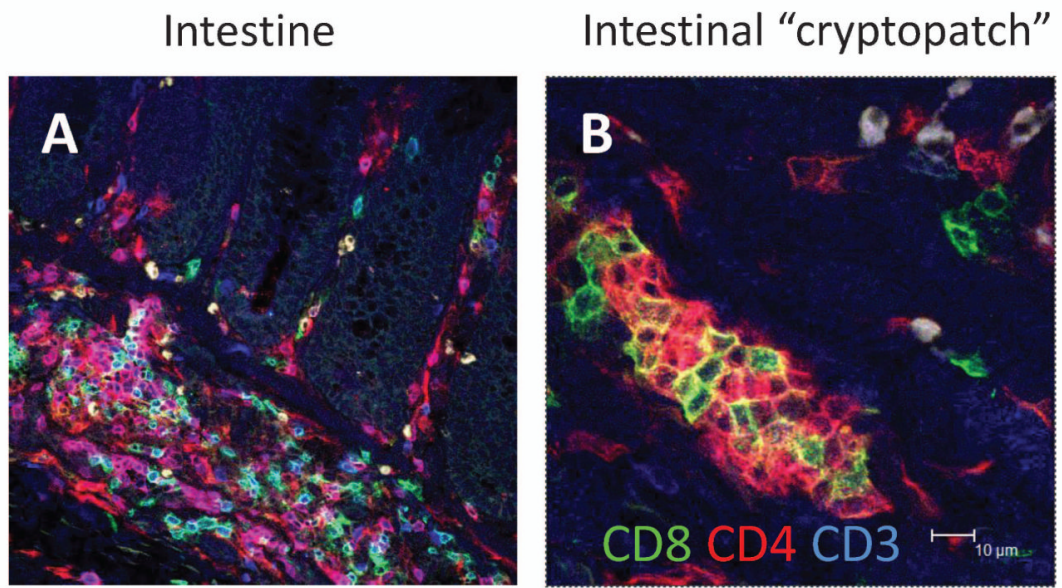

Lymph node
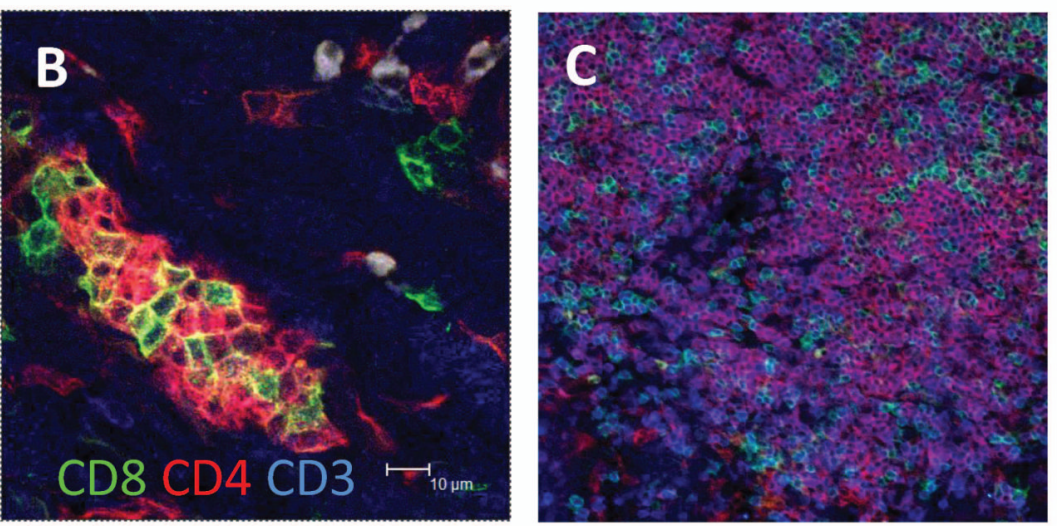

Fig. 5. Comparison of $T$ cells in the intestine and lymph node of macaques

Tissues are stained for CD3 (blue), CD4 (red) and CD8 (green) so CD ${ }^{+} \mathrm{CD}^{+}{ }^{+} \mathrm{T}$ cells appear 'purple' and CD8 ${ }^{+} \mathrm{T}$ cells appear 'yellow'). Note both gut (A) and lymph node (C) contain $\mathrm{CD}^{+}$and $\mathrm{CD}^{+} \mathrm{T}$ cells. However, the intestine contains small 'cryptopatches' containing $\mathrm{CD}^{-}{ }^{-} \mathrm{CD} 4^{+}$cells (red;B) consistent with Lti cells, and $\mathrm{CD}^{-} \mathrm{CD}^{+}$ILC (green), which are not detected in lymph nodes (C). 